\title{
RECURSO EFECTIVO CONTRA LA SENTENCIA QUE NO CONCEDE BENEFICIOS DE LA LEY N 18.216
}

Ignacio Barrientos Pardo*

I.- Comentarios preliminares; II.- Las razones para establecer los medios de impugnación de las resoluciones judiciales; III.- El derecho a recurrir del fallo como garantía minima integrante del debido proceso; IV.- Una mirada a la noción de revisión amplia o integral; $V$.- Racionalidad del sistema de recursos penales en relación a la impugnación de la sentencia definitiva que no concede beneficios de la Ley $N^{\circ}$ 18.216; VI.- Cinco razones para sostener la impugnabilidad de la sentencia denegatoria de beneficios; VII.- La necesidad de un cambio.

\section{I.- Comentarios preliminares.}

Este trabajo se construye sobre la base de una experiencia forense desafortunada. Junto a otros abogados de la Defensoría Penal Pública presentamos un requerimiento de inaplicabilidad cuestionando la constitucionalidad del art. 11 de la Ley $\mathrm{N}^{\circ} 19.806$ que suprimió el recurso de apelación contra la decisión denegatoria de los beneficios de la Ley $\mathrm{N}^{\circ}$ 18.216. Pese a la nula recepción que tuvieron nuestras ideas, persisto en ellas con más fuerza. De entre ellas quiero destacar dos. Por un lado, la necesidad de la eficacia de los mecanismos de impugnación puestos a disposición de los justiciables y, en segundo lugar, la racionalidad de todo sistema procesal.

A partir de esta ideas cuestionaré el actual estado del sistema de recursos del Código Procesal Penal (en adelante, CPP) en un aspecto muy específico: la imposibilidad de impugnar la sentencia condenatoria, dictada en juicio oral, ordinario o simplificado y en un procedimiento simplificado con admisión de responsabilidad, en relación con las medidas alternativas de cumplimiento de la pena.

De la crítica que efectuaré, espero que se puedan extraer argumentos convincentes para modificar la legislación en este aspecto o para repensar el funcionamiento del sistema de recursos en materia penal. De esa manera, la mayor

\footnotetext{
* Licenciado en Ciencias Jurídicas de la Universidad de Valparaíso. Asesor Jurídico de la Defensoría Regional de Antofagasta. Diploma de Estudios Avanzados, Programa de Doctorado "Derechos Fundamentales", Universidad Autónoma de Madrid.

Mi gratitud a mis colegas de la Defensoría Regional de Antofagasta por el apoyo recibido. No puedo dejar de mencionar a quienes, en distintas etapas de este trabajo, gentilmente me han suministrado información valiosa: Cristian Arias, Gonzalo Berríos, Fernando Mardones y Germán Echeverría. Un agradecimiento especial para Enrique Letelier por sus interesantes comentarios y ayuda bibliográfica. Gracias a Julia Arriagada por su trabajo de edición.
} 
Barrientos - Recurso efectivo contra la sentencia...

parte de este trabajo contiene argumentos lege ferenda, en un sentido amplio, esto es, dirigidos tanto a quienes tienen por misión regular el derecho al recurso en los distintos procedimientos como a los que corresponde la función, no menor, de aplicar el derecho al caso concreto.

Para explicar el objeto de este trabajo se requieren dos tipos de comentarios. Uno, que llamaré, a) normativo y, el otro, b) fáctico. En ambos casos lo que se pretende es que el lector comprenda con precisión el punto crítico que suscita este trabajo. Comenzaremos por la observación normativa que da cuenta del cambio que experimentó el sistema procesal penal en materia de medios de impugnación. A continuación haré una breve relación de la situación que originó este trabajo. En último término, formularé el plan argumentativo de este ensayo.

a) Comentario normativo: El recurso de nulidad como medio de impugnación predominante versus la excepcionalidad del recurso de apelación.

La primera característica del nuevo régimen de recursos que se establece en el CPP es la disminución de la intensidad de la vía impugnativa, esto es, de la frecuencia e importancia de su empleo. ${ }^{1}$ Desaparecen, como regla general, los controles verticales, en que las decisiones judiciales, en su mayoría, eran objeto de revisión por un tribunal superior y se sustituyen por otros controles y mecanismos de resguardo de las garantías de víctimas e imputados ${ }^{2}$. En consecuencia, se reduce el ámbito del recurso de apelación y se contempla el recurso de nulidad sólo respecto de sentencias definitivas dictadas en juicios orales, ordinarios y simplificados, y en el procedimiento simplificado con aceptación de responsabilidad. ${ }^{3}$

El fundamento para eliminar el recurso de apelación en el juicio oral reside en la vigencia de la inmediación, esto es, que el fundamento fáctico de la sentencia proviene (y mejor dicho, debe provenir) de la apreciación directa de las pruebas que los jueces obtienen en el juicio. Este argumento procura mantener indemne la

\footnotetext{
${ }^{1}$ Horvitz, María Inés y López Masle, Julián, Derecho Procesal Penal Chileno. Tomo II, Editorial Jurídica de Chile, Santiago de Chile, 2004, p.352.

2 Entre los otros controles y mecanismos alternativos a los recursos procesales tendientes a asegurar los derechos de los intervinientes, se puede mencionar: la cautela de garantía; el amparo ante el juez de garantía; la obligatoriedad de la defensa letrada, como regla general; la facultad de reclamación ante el Fiscal Regional; la nulidad procesal, etc.

3 Este punto que debiera ser pacífico no lo es. De acuerdo a algunos fallos de la Corte de Apelaciones de Talca el recurso de nulidad no es procedente respecto de los procedimientos simplificados con admisión de responsabilidad porque la resolución que los resuelve no tiene el carácter de sentencia definitiva, al no existir un juicio que resolver. Ver sentencias de la Corte de Apelaciones de Talca de 30 de marzo y 18 de abril de 2007, causas Rol N 153-07 y 165-07, respectivamente.
} 
centralidad del juicio oral, evitando la revisión de la sentencia por parte de jueces que no participaron en él, esto es, de jueces menos informados. ${ }^{4}$

Como se sabe la Ley $\mathrm{N}^{\circ} 19.806$ de 2002 (Ley Adecuatoria) $)^{5}$ procuraba adecuar una serie de leyes especiales a las características del nuevo sistema procesal. Por ejemplo, el art. 364 del CPP declaró inapelables las resoluciones dictadas por el tribunal de juicio oral, por lo que, una de las tareas del legislador consistía en adaptar las normas internas a la preferencia que se daba a la oralidad y la inmediación.

Sin embargo, la apelación subsistió, de forma excepcional, tratándose de determinados tipos de resoluciones (sobreseimientos, resolución que ordena alguna restricción de derechos a los intervinientes) y en el procedimiento abreviado, entendiéndose que en ambos casos era necesario el control de dichas decisiones por un tribunal superior. En el caso del procedimiento abreviado, en el que no concurren las razones antes expuestas, especialmente la necesidad de privilegiar la inmediación, pues el juez falla en base a los antecedentes de la investigación, se contempló el recurso de apelación contra la sentencia definitiva.

El recurso de nulidad es el medio de impugnación exclusivo frente a sentencias definitivas de los tribunales orales (tribunales colegiados) y a sentencias dictadas por los tribunales de garantía (compuestos por jueces que actúan unipersonalmente) en procedimientos simplificados con o sin admisión de responsabilidad. En el primero caso, el procedimiento simplificado concluye con la dictación de una sentencia definitiva sin la realización de una audiencia de juicio oral, o sea, sólo con el reconocimiento del imputado y los antecedentes existentes en la carpeta fiscal.

En consecuencia, el recurso de nulidad procede respecto de dos tipos de sentencias definitivas: 1) aquellas dictadas en causas, cuya tramitación concluye, ante un tribunal oral, sea que se refieran a hechos que pueden ser calificados como graves y castigados con penas, por lo general, superiores a presidio menor en su grado máximo, o que digan relación con hechos de mediana gravedad y en que no hubiese prosperado la negociación para arribar a un procedimiento

\footnotetext{
${ }^{4}$ Como lo demuestra la historia del Proyecto de Código Procesal Penal esta no fue una cuestión exenta de polémica. Ver Maturana Miquel, Cristián (Coord.), Reforma Procesal Penal. Génesis, Historia Sistematizada y Concordancias, Tomo III, Código Procesal Penal, Libros Tercero y Cuarto), Editorial Jurídica d Chile, $1^{\circ}$ edición, Santiago de Chile, 2003, p. 57-66, donde destaca la opinión disidente de don Hugo Pereira Anabalón. Del mismo Pereira Anabalón se puede consultar “ Oralidad e instancia única o doble en el proceso penal”, versión digital en Actualidad Jurídica Base de Datos del Diario Oficial, (sin fecha), en la que hace una defensa del recurso de apelación como única forma de cumplir los estándares internacionales en materia de impugnación de las sentencias definitivas dictadas en juicios orales. Para leer un resumen de éste debate durante la tramitación del Proyecto de Código Procesal Penal, también se puede consultar Otero Lathrop, Miguel, Código Procesal Penal, Editorial LexisNexis ConoSur, Santiago de Chile, 2002, pp-118-120.

${ }^{5}$ Publicada en el Diario Oficial el 31 de mayo de 2002.
} 
Barrientos - Recurso efectivo contra la sentencia...

abreviado, y; 2) aquellas dictadas en causas tramitadas, de acuerdo al procedimiento simplificado con o sin admisión de responsabilidad, ante un tribunal de garantía, que traten de hechos de gravedad menor (sancionados con una pena inferior a presidio menor en su grado medio, esto es, una pena inferior a 541 días).

Esto es lo que nos lleva a sostener, si aludimos a los mecanismos recursivos contra sentencias definitivas, que el recurso de nulidad es el medio de impugnación predominante frente a la apelación, pues ésta sólo procede respecto sentencias recaídas en hechos de mediana gravedad que den lugar a la tramitación del procedimiento abreviado, o en que, pese a la mayor gravedad de los hechos, el acuerdo de los intervinientes lo haga procedente.

En relación con el cumplimiento alternativo de la pena, recordemos que la Ley $\mathrm{N}^{\circ} 18.216$ en su antiguo artículo 25 disponía lo siguiente:

Sin perjuicio de las reglas generales sobre apelación y consulta, el condenado también podrá apelar de la decisión denegatoria o revocatoria de los beneficios que establece esta ley, caso en el cual el tribunal de alzada sólo se pronunciará sobre la procedencia o improcedencia del beneficio.

El referido artículo 11 de la Ley $\mathrm{N}^{\circ} 19.806$ dispuso la modificación del art. 25 de la Ley $\mathrm{N}^{\circ} 18.216$, que en su texto actual señala que:

La decisión revocatoria de los beneficios que establece esta ley será apelable ante el tribunal de alzada respectivo.

A lo anterior se agrega que, según jurisprudencia reiterada de la Corte Suprema y de las Cortes de Apelaciones, no es admisible el recurso de nulidad cuando lo que se pretende cuestionar es la no concesión de los beneficios de la Ley $\mathrm{N}^{\circ} 18.216 .^{6}$ En términos muy resumidos la doctrina de la Corte Suprema ${ }^{7}$ sobre la impugnabilidad de la sentencia definitiva en aquella parte que dice relación con las medidas o beneficios alternativos es la siguiente:

\footnotetext{
${ }^{6}$ Los llamados beneficios de la Ley $\mathrm{N}^{\circ} 18.216$ son medidas alternativas de cumplimiento de las penas privativas de libertad, a saber: la remisión condicional de la pena, reclusión nocturna y la libertad vigilada. En este texto, por ceñirnos a la práctica forense, seguiremos empleando esa terminología.

7 Ver sentencias de la Corte Suprema: Rol No 5594, 06/10/87; Rol No 27.085, 0/01/90 (en Gaceta Jurídica, 1990, N 115, p.59); Rol N² 27.666, 12/03/90 (en Gaceta Jurídica, 1990, N 118, p. 48); Rol No 28.507, 13/09/91 (en Gaceta Jurídica, 1991, N 136, p. 84); Rol N 1960-98, 13/08/98; Rol No 1985-04, 08/07/04; Rol N 5097-04, 06/12/04; Rol No 1782-05, 31/05/05; Rol N 131706, 28/03/06 (texto completo de la sentencia que se confirma en Lexis Nexis, Número identificador 34028).
} 
1. Lo concerniente al otorgamiento o no de los beneficios contemplados en la Ley $\mathrm{N}^{0} 18.216$ no forma parte de la sentencia definitiva del proceso penal, cuyo fin es determinar la inocencia o culpabilidad de un acusado.

2. Que no puede superar el examen de admisibilidad un recurso de nulidad que pretenda cuestionar la no concesión de beneficios, pues siendo dicho instituto de derecho estricto sólo procede por las causales expresamente señaladas en la ley y en contra de las resoluciones que por su naturaleza lo hacen procedente.

3. Que si bien las cuestiones relativas a beneficios alternativos se resuelven y se consignan materialmente en la sentencia condenatoria, no participan del carácter de sentencias definitivas, ya que no deciden el asunto que ha sido objeto del pleito, sino tan solo determinan un aspecto adjetivo del mismo. ${ }^{8}$

En consecuencia, en la situación actual, respecto del no otorgamiento de beneficios de la Ley $\mathrm{N}^{\circ} 18.216$, el condenado por sentencia definitiva, dictada en juicio oral, ordinario o simplificado o en procedimiento simplificado con admisión de responsabilidad, no puede recurrir de nulidad ni de apelación.

\section{b) Comentario fáctico: El requerimiento de inaplicabilidad.}

En causa RIT N ${ }^{\circ}$ 77-2006 del Tribunal de Juicio Oral de Calama don F. F.P.A., a quien favorecía, entre otras, la atenuante de irreprochable conducta anterior, fue condenado a la pena de tres años y un día de presidio menor en su grado máximo, más las penas accesorias del caso, por el delito de apropiación indebida, no concediéndosele la libertad vigilada.'

El Tribunal Oral no le concedió la libertad vigilada por las siguientes razones (Párrafo tercero y cuarto del considerando $19^{\circ}$ de la sentencia):

En relación con el acusado, [...], se incorporó informe presentencial que concluye que en virtud de la evaluación realizada el imputado requiere de acciones de tratamiento intensivas e individualizadas de índole terapéutica conducentes al logro de su reinserción social, concluyéndose que un tratamiento en el medio libre no resultaría eficaz, por lo que no se sugiere el ingreso del imputado a la medida alternativa de Libertad Vigilada.

\footnotetext{
${ }^{8}$ Una excelente investigación acerca del origen de este criterio jurisprudencial y su carencia absoluta de logicidad y sustento legal se puede encontrar en Marín González, Juan Carlos, "Algunos Aspectos Procesales de la Ley 18.216", Revista de Estudios de la Justicia No 10, 2008, pp. 63-103. Este artículo tuvo su origen en una solicitud de informe en Derecho realizada por el Departamento de Estudios y Proyectos de la Defensoría Penal Pública, siendo respondida esta solicitud el 1 de septiembre de 2007.

${ }^{9}$ La defensa ante el Tribunal Oral estuvo a cargo del defensor penal público de Calama don Alvaro Rosas Lizama.
} 
Barrientos - Recurso efectivo contra la sentencia...

La defensa, incorporó igualmente, informe social del imputado que señala que éste cuenta en la actualidad con ingresos económicos mínimos para su subsistencia, por lo que no está en condiciones de satisfacer la multa establecida para el delito. Se acompañaron, además ocho certificados de honorabilidad emitidos por particulares y diversas instituciones, que indican que el acusado es una persona responsable, comprometida, trabajadora y con valores éticos. (Subrayado nuestro).

En noviembre de 2006 la defensa, previa interposición de un recurso de nulidad fundado en una errónea aplicación del derecho, dedujo requerimiento de inaplicabilidad por inconstitucionalidad en contra del artículo 11 de la Ley $\mathrm{N}^{\circ}$ 19.806, que modificó, entre otros textos legales, la Ley $\mathrm{N}^{\circ} 18.216$. El fundamento del requerimiento partía de la base que aquella norma no cumplía con el mandato constitucional y supranacional de revisión judicial, al impedir cuestionar la no concesión de beneficios. ${ }^{10}$

El requerimiento presentado por la defensa fue declarado admisible por la Segunda Sala del Tribunal Constitucional. No obstante, con fecha 6 de abril de 2007 el Pleno del Tribunal Constitucional dictó sentencia negando lugar al requerimiento por razones formales. El Tribunal señaló que

[...] no obstante haberse pronunciado la Segunda Sala de esta Magistratura a favor de la admisibilidad del requerimiento, un examen del mismo, a la luz de todos los antecedentes presentados $y$, particularmente, de los vertidos en la vista de la causa, permite colegir que la acción deducida no satisface uno de los requisitos de admisibilidad, cual es que la aplicación de la norma impugnada pueda resultar decisiva en la resolución del asunto pendiente

En efecto, siendo la cuestión pendiente la tramitación de un recurso de nulidad en contra de la sentencia condenatoria que afecta al requirente, la aplicación de la norma legal modificatoria que éste objeta en ningún caso podría tener lugar en la resolución de tal recurso, por no ser norma que incida en la decisión de la cuestión debatida.

En el Considerando Sexto, agrega que

[...] a mayor abundamiento, la pérdida de la eficacia normativa del primitivo texto del art. 25 de la ley 18.216 (que contemplaba, como se ha dicho la posibilidad de apelar contra la denegación de medidas alternativas) no sólo se produjo con la introducción del precepto modificatorio que el requirente tacha de inconstitucional

\footnotetext{
${ }^{10}$ El requerimiento de inaplicabilidad fue suscrito por los abogados de la Defensoría Penal Pública doña Loreto Flores Tapia, don Cristián Arias Vicencio, don Alvaro Rosas Lizama y el autor. El Tribunal Constitucional asignó al requerimiento el Rol Nº 670-2006.
} 
(el art. 11 de la Ley $\mathrm{N}^{\circ}$ 19.806), sino que, incluso antes, por aplicación del dispuesto en el art. 364 del Código Procesal penal, que no fue objetado en el requerimiento materia de autos y que expresamente suprimió la apelación contra las resoluciones dictadas por un tribunal de juicio oral en lo penal.

Posteriormente, alzada la suspensión del procedimiento, la Corte de Apelaciones de Antofagasta mediante resolución de 23 de mayo de 2007, rechazó el recurso de nulidad, señalando:

Que la jurisprudencia en forma reiterada ha resuelto que el recurso de nulidad se ha concedido como un recurso de derecho estricto al que se accede solamente en virtud de las causales y para los fines consagrados en la ley. Por lo tanto, no constituye una instancia en que se puedan revisar los hechos establecidos en el juicio, ni extenderse a otros aspectos criticables del fallo, que no han sido materia de su presentación. ${ }^{11}$

Aclaro que el presente trabajo no analiza la sentencia del Tribunal Constitucional, pues no hubo pronunciamiento sobre el fondo de la cuestión planteada. Sin embargo, como puede resultar obvio, no comparto las razones del rechazo del requerimiento, especialmente porque nunca se discutió la existencia y significado del art. 364 del CPP. Al contrario se partía de la base de su vigencia. Además, no es sostenible la afirmación que la inaplicabilidad del art. 11 de la Ley $\mathrm{N}^{\circ} 19.806$ no tiene influencia en la decisión de la cuestión debatida, pues ello puede interpretarse en el sentido de que sólo las normas sustantivas tienen carácter decisorio, excluyendo las normas procesales del ámbito de acción del requerimiento de inaplicabilidad. ${ }^{12}$ Argumentación, por cierto, que va en contra de la propia jurisprudencia del Tribunal Constitucional. ${ }^{13}$

c) Plan argumentaivo del trabajo.

La pretensión de este trabajo es analizar y explicar si el sacrificio del derecho al recurso está, en relación con la impugnación del no otorgamiento de medidas alternativas de cumplimiento de la pena, justificado racional y

\footnotetext{
$11 \mathrm{Al}$ recurso de nulidad se le asignó el Rol N²21-06.

12 En el sentido afirmado se puede consultar la causa Rol N ${ }^{\circ} 764-07$ en que el Tribunal Constitucional señaló, refiriéndose al art. 387 inciso $2^{\circ}$ del Código Procesal Penal, que: "En este caso, la norma legal invocada no tiene incidencia en la decisión sustantiva de la gestión que ha motivado la interposición de la acción, atendida la naturaleza de la misma."

${ }^{13}$ Sobre el particular se puede aludir a la copiosa jurisprudencia del Tribunal Constitucional sobre la inaplicabilidad del art. 116 del Código Tributario y del art. 416 del Código Procesal Penal (desafuero parlamentario). Recientemente, la sentencia del Tribunal Constitucional dictada en causa Rol N 986-2007 (30 de enero de 2008) que resuelve un requerimiento de inaplicabilidad del mismo art. 387 inciso $2^{\circ}$ del Código Procesal Penal, superó la injustificada distinción entre leyes decisorias y ordenadoras de la litis.
} 
Barrientos - Recurso efectivo contra la sentencia...

sistémicamente. ${ }^{14}$ A mi juicio, la justificación puede ser en este punto de dos clases: una justificación intrinseca y una justificación extrínseca. La primera, procura responder a la pregunta de si, la no impugnabilidad de la sentencia definitiva en cuanto no otorga beneficios de la Ley $\mathrm{N}^{\circ} 18.216$, está fundada en buenas razones que pueden ser comunicadas racionalmente. La segunda clase de justificación busca contestar a la pregunta acerca de la justificación de dicha clausura recursiva dentro de un contexto normativo más amplio, esto es, en relación con el sistema normativo nacional y supranacional del que nuestro sistema procesal penal forma parte.

En primer lugar, y desde una perspectiva muy general, me parece conveniente analizar las razones que doctrinariamente se exigen para establecer la impugnabilidad de las resoluciones judiciales. Este paso es necesario para argumentar sobre si los requisitos o supuestos generales que recomiendan la instauración de un recurso procesal respecto de una resolución concurren o no en el caso que se comenta.

En segundo término, me ocuparé de dos aspectos, que resultarán en definitiva trascendentales para argumentar en favor del establecimiento de un recurso efectivo en la situación comentada. El primero de ellos se refiere al derecho al recurso como garantía minima integrante del debido proceso. El otro, íntimamente vinculado con el anterior, recaerá sobre la noción de revisión amplia o integral. Ambos serán objeto de un análisis lo más exhaustivo posible, con la finalidad de recolectar argumentos en favor de nuestra posición.

A continuación, evaluaré criticamente la racionalidad del sistema recursivo chileno en relación a la impugnación de la sentencia definitiva que no concede beneficios de la Ley $\mathrm{N}^{\circ} 18.216$.

Finalmente, aplicando la normativa internacional invocada, la noción de revisión integral y las críticas sostenidas respecto de la racionalidad del sistema recursivo propondré las razones que justifican la impugnabilidad de la sentencia que deniega beneficios de la Ley $\mathrm{N}^{\circ} 18.216$ y la necesidad de un cambio legislativo y judicial.

\footnotetext{
14 Sólo tangencialmente se aborda el debate sobre la adecuación del sistema de recursos del ordenamiento chileno al Sistema Interamericano y de Naciones Unidas. No obstante, ese no es el objetivo de este trabajo. En esta oportunidad sólo reflexionaremos acerca del cierre de la vía recursiva en el juicio oral y en el procedimiento simplificado, respecto de una parte de la sentencia definitiva concerniente a la denegación de beneficios de la Ley $\mathrm{N}^{\circ} 18.216$, que tiene la virtualidad de causar perjuicio a los intereses y/o derechos de un justiciable.
} 
REJ - Revista de Estudios de la Justicia - No 11 - Año 2009

\section{II.- Las razones para establecer los medios de impugnación de las resoluciones judiciales.}

Los supuestos de los que parto en este artículo son muy simples. Los recursos procesales existen como medios de control para que la o las partes afectadas, frente a una decisión que estiman errónea, puedan impugnar la resolución judicial que les causa perjuicio en algún bien jurídico relevante.

Como se sabe, un primer requisito para formular la existencia (y la necesidad) de un recurso procesal es la posibilidad de que a través de una resolución judicial se incurra en un error, sea que éste recaiga sobre las formas procesales, la valoración de las pruebas rendidas o el derecho aplicable. En este sentido, conviene recordar que la concepción de los recursos como mecanismos de control de la actividad jurisdiccional se justifica desde dos perspectivas fundamentales: Una, como un derecho de impugnación, ligado al valor de "seguridad jurídica" y como un medio para evitar los errores judiciales en el caso concreto; la otra perspectiva se basa en la necesidad social de que las decisiones judiciales sean correctas (o cumplan su función pacificadora), y el Derecho sea aplicado de un modo uniforme y equitativo. ${ }^{15}$

En la actualidad, el recurso es concebido, antes que un medio de control estatal, como una garantía procesal, principalmente, en favor del imputado, destinada a la revisión de una decisión jurisdiccional que se sospecha errónea y a la evitación de sus consecuencias perjudiciales. Pero, probablemente, el fundamento de los recursos no sólo está constituido por la necesidad de precaver o evitar el error judicial, sino que, por sobretodo, evitar la injusticia del fallo. En definitiva, antes que una sentencia pura, a los justiciables les interesa una decisión justa. ${ }^{16} \mathrm{El}$ recurso, según el profesor Raúl Tavolari, "persigue establecer tanto si la obtención de la conclusión es corolario de actos efectuados con sujeción a los modelos legales preanticipados como si, en el fondo dicha conclusión satisface requerimientos de justicia (o de legalidad)". ${ }^{17}$ No debe olvidarse que la justicia es la meta del acto jurisdiccional y que una resolución justa es una condición para obtener, con mayores probabilidades, una efectiva pacificación social. ${ }^{18}$ Los recursos son precisamente medios de impugnación puestos a disposición de las partes para alcanzar esa meta.

\footnotetext{
${ }^{15}$ Binder, Alberto, Introducción al derecho procesal penal, Ad-Hoc, Bs. Aires, Tercera Reimpresión, 2004, p. 286.

${ }^{16}$ Le debo esta idea a Enrique Letelier L., Profesor Titular de Derecho Procesal de la Universidad de Antofagasta.

${ }_{17}$ Tavolari, Raúl, Habeas Corpus. Recurso de Amparo, Ed. Jurídica de Chile, Santiago de Chile, 1995, p. 92.

18 Clariá Olmedo, Jorge A., Derecho Procesal, Tomo II. Estructura del Proceso, Ediciones Depalma, Buenos Aires, 1983, p.273.
} 
Barrientos - Recurso efectivo contra la sentencia...

De las afirmaciones precedentes surge la conveniencia del establecimiento de un sistema recursivo en que, por ejemplo, sea realidad la eliminación de innecesarias formalidades de interposición de los recursos, la aplicación en el examen de admisibilidad del principio pro actione y la ampliación del ámbito de la revisión del fallo. La concepción de la justicia del caso individual como fin y fundamento de los recursos, condujo al Procurador General de la Corte Suprema argentina en el caso "Casal" de 20 de septiembre de 2005 a afirmar que la necesidad de compatibilizar los fines históricos de la casación -aseguramiento de la unidad del derecho y proveer la solución justa para el caso concreto- ha obligado a la jurisprudencia y doctrina a desarrollar estrategias para ampliar las posibilidades de revisión, incluso a pesar de la falta de cambios legislativos, recurriendo, por ejemplo, a examinar el deber de fundamentación de las sentencias en cuanto vehículo para revisar la aplicación de la reglas de la lógica. Desaparecido, o por lo menos atenuado, el fin político de la casación el derecho al recurso significa un control de calidad de la justicia y corrección de la sentencia, que requiere ser amplio y no formalista. ${ }^{19}$

El segundo requisito es que la resolución judicial, estimada errónea, ocasione un agravio, gravamen o perjuicio a los intereses de una persona ${ }^{20}$, cualquiera que sea la concepción de aquél, esto es, sea que se le estime un presupuesto subjetivo básico de los recursos, constituido por la diferencia, en contra del recurrente, entre lo que pidió y se le concedió y que permite calificarlo de vencido, así no más sea en parte ${ }^{21}$, o que se le considere un presupuesto general material de la interposición de recursos. ${ }^{22}$

La existencia del interés en impugnar una resolución judicial es un requisito subjetivo de admisibilidad de los recursos que exige que quien los interpone haya sufrido un perjuicio o gravamen a raíz de la resolución que impugna. ${ }^{23}$ Este interés, en el caso de las sentencias definitivas, contribuye a configurar legalmente un recurso procesal, cuando se afecta un bien jurídico que se considera relevante en el sistema constitucional. En el caso concreto esto involucrará que en la medida que la persecución penal puede afectar el derecho a la libertad personal, la resolución que niega el cumplimiento alternativo de una pena privativa de libertad debe ser siempre susceptible de impugnación.

El control, como principio rector de cualquier sistema procesal, se basa en cuatros pilares, que conviene siempre tener en cuenta: a) La sociedad debe controlar cómo sus jueces administran justicia; b) El sistema de justicia penal debe

\footnotetext{
${ }^{19}$ Informe del Procurador General de la Corte Suprema argentina en el caso "Casal”, Dr. Esteban Righi, de 9 de agosto de 2005, considerandos X y XI.

20 Tavolari, Raúl, Comentarios Procesales, Edeval, Valparaíso, 1994, p. 38.

${ }^{21}$ Ibidem, p. 53.

22 Roxin, Claus, Derecho Procesal Penal, Editores del Puerto, Bs. Aires, 2000, p.448.

23 Palacio, Lino Enrique, Los recursos en el proceso penal, Ed. Abeledo-Perrot, Buenos Aires, 1998, p.

17.
} 
desarrollar mecanismos de autocontrol, para permitir la planeación institucional; c) Los sujetos procesales tienen interés en que la decisión judicial sea controlada; d) $\mathrm{Al}$ Estado le interesa controlar cómo sus jueces aplican el derecho. ${ }^{24}$ Como se verá más adelante el acento de este artículo se pone en el tercer pilar, pues de la relevancia de ese interés surge el derecho al recurso.

En consecuencia, nuestro planteamiento en este trabajo será el siguiente: Una resolución que no concede algún beneficio de la Ley $\mathrm{N}^{\circ} 18.216$, solicitado por la defensa, causa al acusado un agravio que se traduce en la afectación de su libertad personal que, como decisión jurisdiccional, necesita del establecimiento de mecanismos de control, a fin de evitar el error judicial en la valoración de los antecedentes que fundan la resolución ${ }^{25}$.

\section{III.- El derecho a recurrir del fallo como garantía mínima integrante del debido proceso.}

Frente a la pregunta, ¿qué significa el "derecho a recurrir el fallo ante un juez o tribunal superior?, existen muchas respuestas. Por ejemplo, Alberto Binder señala que la interpretación correcta del "derecho a recurrir" es la que indica que el derecho fundamental consiste en la facultad de desencadenar un mecanismo real y serio de control del fallo, por un funcionario distinto del que lo dictó y dotado de poder para revisar el fallo anterior, es decir, que su revisión no sea meramente declarativa, sino que tenga efectos sustanciales sobre el fallo. ${ }^{26}$ El espíritu de la Convención Americana de Derechos Humanos, según A. Binder, es que todas las resoluciones judiciales que producen algún agravio deben poder ser recurridas por todas las personas que intervienen en ese proceso. ${ }^{27}$ Para Julio Maier, en cambio, tiene un significado distinto, ya que, en su opinión, "el derecho al recurso" del condenado significa, básicamente "el derecho a lograr un nuevo juicio", cuando mediante el recurso se comprueba que la condena, por fallas jurídicas en el procedimiento, en la percepción directa de los elementos de prueba por parte del tribunal que la dictó o, incluso, por fallas en la solución jurídica del caso, no puede ser confirmada como intachable (regla de la doble conforme). ${ }^{28}$

\footnotetext{
${ }^{24}$ Ibidem..

${ }^{25}$ Uso la expresión "antecedentes" en el sentido empleado por el legislador en el art. 343 inciso final del Código Procesal Penal.

${ }^{26}$ Ibidem, p. 285.

27 La Comisión Interamericana en Caso 11.137, Informe 55/97 (CIDH/OEA/ser/L/V/II.97) sostuvo que "el derecho previsto en el artículo 8.2.h requiere la disponibilidad de un recurso que al menos permita la revisión legal, por un tribunal superior, del fallo y de todos los autos procesales importantes".

28 Maier, Julio Bernardo J., Derecho Procesal Penal, I. Fundamentos, Editores del Puerto, $2^{\circ}$ edición, $2^{\circ}$ Reimpresión, Buenos Aires, 2002, p. 720. Esta posición de J. Maier es persistente, pues en otra parte de su obra sostiene que “... el derecho a impugnar la condena representa, para el condenado fundamentalmente, el derecho a intentar que se le conceda un nuevo juicio, si demuestra irregularidades en el primero tocantes a aquello que se comprende como un "juicio justo", p. 716.
} 
Barrientos - Recurso efectivo contra la sentencia...

De este modo la impugnabilidad de la sentencia y de otros fallos importantes se vincula a las garantías judiciales mínimas. ${ }^{29}$ En consecuencia, un proceso penal garantizador debe establecer el derecho o la facultad de recurrir del fallo de parte del agraviado, a fin de evitar que se concrete el error que se imputa a la resolución.

Para una completa y correcta determinación del derecho al recurso como garantía mínima es necesario analizar qué significados tiene este derecho en los diversos tratados que ha suscrito y ratificado Chile y en las normas constitucionales internas.

A continuación, examinaremos, por separado, cada una de esas normas. Nos referimos, 1) al Pacto Internacional de Derechos Civiles y Políticos (en adelante, el PIDCP); 2) a la Convención Americana de Derechos Humanos (en adelante, $\mathrm{CADH}$ ), y; 3) a la Constitución Política de la República de Chile (en adelante, CPR). En cada caso se intercalarán los dictámenes y sentencias jurisdiccionales a que se ha tenido acceso. ${ }^{30}$

\section{1.- El derecho a recurrir en el Pacto Internacional de Derechos Civiles y Políticos.}

El PIDCP en su artículo 14.5 expresa que:

[T] oda persona declarada culpable de un delito tendrá derecho a que el fallo condenatorio y la pena que se le haya impuesto sean sometidos a un tribunal superior conforme a lo prescrito en la ley.

El Comité de Derechos Humanos de Naciones Unidas, a requerimiento de ciudadanos de distintos países miembros de la organización internacional, ha determinado el contenido esencial del derecho al recurso. Entre los varios casos, por ser lo más conocidos, se pueden citar los siguientes: V. Domukovsky y otros v. Georgia (626/1995), dictamen de 6 de abril de 1998, párr.; C. Gómez Vásquez c. España (701/1996), dictamen de 20 de julio de 2000, párr. 11.1, y; M. Sineiro Fernández. c. España (1007/2001), dictamen de 7 de agosto de 2003, párr. 7 y 8. ${ }^{31}$

\footnotetext{
${ }^{29}$ Se puede consultar Considerando $5^{\circ}$ del voto concurrente del Juez de la Corte Interamericana don Sergio Garcia Ramírez, "Herrera Ulloa c. Costa Rica, en que sostiene que el derecho a recurrir es una manifestación más del derecho de defensa, y con él, integra la noción de debido proceso. Sobre la integración del derecho de defensa en el concepto de debido proceso se puede consultar Caroca, Alex, Garantía Constitucional de la Defensa Procesal, Ediciones Jurídicas Olejnik-José María Bosch Editor, Barcelona-Santiago de Chile, 1998, p. 185.

30 Conforme al actual texto del inciso $2^{\circ}$ del art. 5 de la Constitución Política, los tratados internacionales de derechos humanos, suscritos y ratificados por Chile, conforman derecho interno chileno, sin perjuicio del debate sobre la jerarquía normativa de los tratados internacionales.

$31 \mathrm{Al}$ respecto se pueden consultar también las comunicaciones: 1110/2002, Rolando c. Filipinas, párr. 4.5; 984/2001, Juma c. Australia, párr. 7.5; 536/1993, Perera c. Australia, párr. 6.4; 1156/2003, Pérez. Escolar c. España, párr. 9.3; 1389/2005, Bertilli Gálvez. c. España, párr. 4.5.
} 
REJ - Revista de Estudios de la Justicia - No 11 - Año 2009

El Comité en el caso Domukovsky y otros v. Georgia, señaló que

[...] observa que, de conformidad con la información que obra en su poder, los autores no podían apelar el fallo condenatorio y la pena, pero que la ley prevé únicamente una revisión judicial, que aparentemente se realiza sin una audiencia pública y versa únicamente sobre cuestiones de derecho. El Comité opina que esta clase de revisión no reúne los requisitos previstos en el párrafo 5 del artículo 14 del Pacto, en que se requiere una evaluación plena de las pruebas y de las incidencias del juicio y que se vulneró esta disposición respecto de cada uno de los autores. (Considerando 18.11) (Subrayado del autor)

En el segundo de los $\operatorname{casos}^{32}$, examinando una denuncia contra España sobre violación del derecho a recurrir, concluye

[...] que la inexistencia de la posibilidad de que el fallo condenatorio y la pena del autor fueran revisadas íntegramente, como se desprende de la propia sentencia de casación $[\ldots]$, limitándose dicha revisión a los aspectos formales o legales de la sentencia, no cumple con las garantías que exige el párrafo 5 , artículo 14 del Pacto. Por consiguiente, al autor le fue denegado el derecho a la revisión del fallo condenatorio y de la pena, en violación del párrafo 5 del artículo 14 del Pacto. (Considerando 11.1) (Subrayado nuestro)

Ante la alegación del Estado español en cuanto a la denominación del recurso, el Comité concuerda que el Pacto no exige que el recurso de revisión se llame apelación. En realidad, y esto es lo importante, al Comité, independientemente de la nomenclatura, le interesa que el recurso que exista cumpla con los elementos que establece el Pacto y que implique una revisión íntegra.

En el caso M. Sineiro Fernández c. España, el Comité señaló, basándose en la jurisprudencia sentada en Gómez Vázquez, c. España, que al reconocer el Tribunal Supremo que dentro de sus funciones no se encuentra la realización de una nueva valoración del material probatorio en el que se basó el juzgador en primera instancia para dictar su fallo de condena, se le negó al autor de la comunicación, "...la revisión íntegra de la sentencia y del fallo condenatorio".

\footnotetext{
32 Un análisis del caso Gómez Vázquez c. España se puede encontrar en Fairén Guillén, Victor, "Apresurado comentario al "informe" o "exposición” del Comité de Derechos Humanos de la Organización de las Naciones Unidas en el caso "Gómez Vásquez v. España” (10-28 de julio de 2000)", Revista de Derecho Procesal, $N^{\circ}$ 3, año 2000, pp. 591-619. También hay una referencia al caso antes mencionado en Bacigalupo, Enrique, "Doble Instancia y principio de inmediación”, Derecho Penal y el Estado de Derecho, Editorial Jurídica de Chile, Santiago de Chile, 2005, pp-251-282.
} 
Barrientos - Recurso efectivo contra la sentencia...

No obstante, se puede observar, en el Comité, cierto cambio en la interpretación de los elementos o requisitos del derecho al recurso. En posteriores dictámenes, el Comité ya no exige una nueva vista de los hechos, sino que requiere que exista una evaluación de las pruebas presentadas durante el juicio y de la forma en que se desarrolló éste. ${ }^{33}$

Por ejemplo, desde 2002 las quejas contra España por supuestas violaciones al art. 14.5 del Pacto han sido rechazadas. Así ha ocurrido en Cuartero Casado c. España (1399/2005); Parra Corral c. España (1356/2005); Bertelli Gálvez c. España (1389/2005); Pérez Escolar c. España (1156/2003) y Carvallo Villar c. España $(1059 / 2002)$. En términos generales, el fundamento de la declaración de inadmisibilidad o rechazo se encuentra en que de la nueva jurisprudencia del Tribunal Supremo se desprende que éste ha examinado con detenimiento la valoración de las pruebas hecha por los tribunales inferiores y que a ese respecto, el Tribunal Supremo, ha considerado que los elementos de prueba presentados contra el autor son suficientes para contrarrestar la presunción de inocencia que le favorecía.

Esta doctrina fue recientemente confirmada por el Comité en su Observación General No 32, sobre el "Artículo 14. El derecho a un juicio imparcial y a la igualdad ante los tribunales y cortes de justicia", de 23 de agosto de $2007^{34}$, en que afirma que:

El derecho de toda persona a que el fallo condenatorio y la pena impuesta se sometan a un tribunal superior, establecido en el párrafo 5 del artículo 14, impone al Estado Parte la obligación de revisar sustancialmente el fallo condenatorio y la pena, en lo relativo a la suficiencia tanto de las pruebas como de la legislación, de modo que el procedimiento permita tomar debidamente en consideración la naturaleza de la causa Una revisión que se limite a los aspectos formales o jurídicos de la condena solamente no es suficiente a tenor del Pacto. Sin embargo, el párrafo 5 del artículo 14 no exige un nuevo juicio o una nueva "audiencia" si el tribunal que realiza la revisión puede estudiar los hechos de la causa. Así pues, por ejemplo, no se viola el Pacto si un tribunal de instancia superior examina con todo detalle las alegaciones contra una persona declarada culpable, analiza los elementos de prueba que se presentaron en el juicio y los mencionados en la apelación y llega a la conclusión de que

\footnotetext{
33 Comunicaciones $\mathrm{N}^{\circ} 1100 / 2002$, Bandajevsky c. Belarus, párr. 10.13; 985/2001, Aliboeva c. Tayikistán, párr. 6.5; 973/2001, Khalilova c. Tayikistán, párr. 7.5; 964/2001, Saidova c. Tayikistán, párr. 6.5; 802/1998, Rogerson c. Australia, párr. 7.5; 662/1995, Lumley c. Jamaica, párr. 7.3. 34 Comité de Derechos Humanos, $90^{\circ}$ período de sesiones, Ginebra, 9 a 27 de julio de 2007, CCPR/C/GC/32.
} 
hubo suficientes pruebas de cargo para justificar el dictamen de culpabilidad en el caso de que se trata ${ }^{35}$." (Subrayado nuestro)

En la cuestión específica que suscita este trabajo el Sistema de Naciones Unidas también ha provisto de una interpretación. De acuerdo a las Reglas Mínimas de las Naciones Unidas sobre las Medidas No Privativas de la Libertad (Reglas de Tokio) ${ }^{36}$ :

5. Las decisiones sobre la imposición de medidas no privativas de la libertad estarán sometidas a la revisión de una autoridad judicial $\mathrm{u}$ otra autoridad competente e independiente, a petición del delincuente.

Las Reglas de Tokio permiten interpretar el artículo 14.5 del Pacto cuando se refiere "al fallo condenatorio y la pena", de manera tal de incluir lo concerniente a las medidas no privativas de libertad dentro del objeto pasible de revisión. No tiene cabida una exégesis estricta del citado precepto, por lo demás inadmisible en materia de derechos fundamentales, pues la pena, aspecto sustancial de la sentencia definitiva en cuanto equivale a la fijación del quantum del ius puniendi ejercido en un caso concreto, incluye la forma de cumplimiento entendida como la modalidad de efectiva ejecución del quantum fijado. Este constituye un fuerte argumento de texto para sostener la impugnabilidad de la no concesión de los beneficios de la Ley $\mathrm{N}^{\circ}$ $18.216 .^{37}$

En consecuencia, el Sistema de Naciones Unidas, aunque no exige una nueva audiencia o un nuevo juicio, permite sostener que el derecho al recurso se satisface solamente con la evaluación plena o revisión integral de las pruebas, y que sólo un recurso que, no restringiéndose a cuestiones de derecho o aspectos formales o legales de la sentencia, permita una nueva revisión del material probatorio, merece ser calificado de eficaz o efectivo. Como se ha sostenido desde 2002 por el Comité de Derechos Humanos, lo anterior no significa reinstaurar la segunda instancia, sino más bien la ampliación de la casación. ${ }^{38}$

\footnotetext{
${ }^{35}$ El Tribunal Europeo de Derechos Humanos así parece entenderlo en el caso "Krombach v. France" (sentencia de 13 de febrero de 2001) en que expresa que: "El Tribunal sostiene que el que hecho que el reclamante no pudiese recurrir a la Corte de Casación contra la sentencia emitida por el tribunal (assize court) actuando como primera y última instancia le ha privado del derecho que su condena sea examinada por un tribunal superior y, en particular, de cualquier posibilidad de garantizarle una revisión por la Corte de Casación acerca de la legalidad del rechazo del tribunal de permitirle a sus defensores formular presentaciones."

${ }^{36}$ Las Reglas de Tokio, fueron adoptadas por Resolución 45/110, de 14 de diciembre de 1990 en la Asamblea General de Naciones Unidas.

${ }^{37}$ Ver la sección VI, Conclusiones. 1.-Naturaleza penal de los beneficios de la Ley $\mathrm{N}^{\circ} 18.216$.

38 Ver la Sección IV. 2 y 3.
} 
Barrientos - Recurso efectivo contra la sentencia...

Para que esa eficacia o efectividad sea absoluta, siguiendo lo estatuido en las Reglas de Tokio, la revisión debe extenderse a las medidas no privativas de libertad, siempre que así lo solicite el condenado.

\section{2.- El derecho a recurrir en la Convención Americana de Derechos Humanos.}

El artículo 8.2.h. de la CADH dispone que durante el proceso, toda persona tiene derecho, en plena igualdad, "a recurrir del fallo ante juez o tribunal superior".

En un primer momento, la Comisión Interamericana sostuvo una tesis menos fuerte acerca del derecho al recurso. En el Informe Anual $\mathrm{N}^{\circ} 24 / 92$, sobre la situación del derecho al recurso en Costa Rica, de 2 de octubre de 1992, la Comisión, después de analizar una serie de casos planteados, concluye

30. Que el recurso de casación es una institución jurídica que, en tanto permite la revisión legal por un tribunal superior del fallo y de todos los autos procesales importantes, incluso de la legalidad de la producción de la prueba, constituye un instrumento efectivo para poner en práctica el derecho reconocido por el artículo 8.2.h de la Convención.

Siguiendo a la Sala Constitucional de la Corte Suprema costarricense, a la Comisión le bastaba, en 1992, para que el recurso de casación cumpliese los requerimientos de la Convención, que dicho medio impugnativo no se regulase, interpretase o aplicase con rigor formalista sino que, por el contrario, permitiese con relativa sencillez el examen de la validez de la sentencia recurrida y el aseguramiento de los derechos fundamentales del imputado, especialmente los de defensa y debido proceso.

Sin embargo, en el caso "Herrera Ulloa vs. Costa Rica" (Sentencia de 2 de julio de 2004) la Corte Interamericana de Derechos Humanos (en adelante CIDH) se enriela en la misma línea doctrinal del Comité de Derechos Humanos ${ }^{39}$ y entiende que

[...] el derecho de recurrir del fallo es una garantía primordial que se debe respetar en el marco del debido proceso legal, en aras de permitir que una sentencia adversa pueda ser revisada por un juez o tribunal distinto y de superior jerarquía orgánica. El derecho de interponer un recurso contra el fallo debe ser garantizado antes

\footnotetext{
39 La Corte Interamericana, recurriendo a su propia doctrina de emplear para su razonamiento normas internacionales externas al Sistema Interamericano, cita en la sentencia "Herrera Ulloa c. Costa Rica", lo resuelto por el Comité de Derechos Humanos de la Naciones Unidas en los casos Gómez. Vásquez. c. España y Sineiro Fernández c. España.
} 
REJ - Revista de Estudios de la Justicia - No 11 - Año 2009

de que la sentencia adquiera calidad de cosa juzgada. Se busca proteger el derecho de defensa otorgando durante el proceso la posibilidad de interponer un recurso para evitar que quede firme una decisión que fue adoptada con vicios y que contiene errores que ocasionarán un perjuicio indebido a los intereses de una persona. (Párr.158)

En una interpretación fuerte del derecho al recurso la CIDH no vacila en sostener que este derecho,

[...] no se satisface con la mera existencia de un órgano de grado superior al que juzgó y condenó al inculpado, ante el que éste tenga o pueda tener acceso. Para que haya una verdadera revisión de la sentencia, en el sentido requerido por la Convención, es preciso que el tribunal superior reúna las características jurisdiccionales que lo legitiman para conocer del caso concreto. (Párr. 159) (Subrayado del autor)

Recurriendo al principio de buena fe en la interpretación de los tratados (artículo 31.1 de la Convención de Viena sobre el Derecho de los Tratados de 1969) y de acuerdo al objeto y fin de la Convención Americana, que no es otro que la eficaz protección de los derechos humanos ${ }^{40}$,

[...] se debe entender que el recurso que contempla el artículo 8.2.h. de dicho tratado debe ser un recurso ordinario eficaz mediante el cual un juez o tribunal superior procure la corrección de decisiones jurisdiccionales contrarias al derecho. $\underline{\mathrm{Si} \text { bien los }}$ Estados tienen un margen de apreciación para regular el ejercicio de ese recurso, no pueden establecer restricciones o requisitos que infrinjan la esencia misma del derecho de recurrir del fallo. (Párr. 161) (Subrayado del autor)

Concretamente sobre la eficacia, la CIDH ha establecido que:

$[\mathrm{N}]$ o basta con la existencia formal de los recursos sino que éstos deben ser eficaces", es decir, deben dar resultados o respuestas al fin para el cual fueron concebidos (Párr. 161).

\footnotetext{
${ }^{40} \mathrm{La}$ Corte Interamericana ha recurrido frecuentemente al principio de buena fe, como criterio de interpretación de los tratados internacionales. Así lo demuestran los siguientes casos: Caso Baena Ricardo y otros. Competencia, sentencia de 28 de noviembre de 2003, Serie C N ${ }^{\circ}$ 104, párr. 95; Caso Cantos. Excepciones Preliminares, sentencia de 7 de septiembre de 2001, Serie C N 85, párr. 37; y Caso Constantine y otros. Excepciones Preliminares, sentencia de 1 de septiembre de 2001, Serie C No 82, párr. 86.
} 
Barrientos - Recurso efectivo contra la sentencia...

La CIDH, en relación con los deberes especiales vinculados al acceso a los recursos y a la accesibilidad de los mismos, entiende que el juez o tribunal superior encargado de resolver el recurso interpuesto contra la sentencia penal tiene el deber especial de protección de las garantías judiciales y el debido proceso a todas las partes que intervienen en el proceso penal de conformidad con los principios que lo rigen y que la posibilidad de "recurrir del fallo" debe ser accesible, sin requerir mayores complejidades que tornen ilusorio este derecho. ${ }^{41}$

Insistiendo en una interpretación fuerte del derecho comentado, señala que:

Independientemente de la denominación que se le de al recurso existente para recurrir un fallo, lo importante es que dicho recurso garantice un examen integral de la decisión recurrida. (Párr. 165)

$\mathrm{Al}$ afirmar la Corte Interamericana que lo que se requiere, para que el recurso sea eficaz, es una revisión integral de la sentencia, sigue al pie de la letra lo resuelto por el Comité de Derechos Humanos en los casos Gómez contra España y Sineiro contra España.

Pero es el Párrafo 167 de "Herrera Ulloa", en que la Corte configura lo que entiende por revisión integral. En el caso mencionado la Corte exige que el recurso sea

[...] amplio de manera tal que permitiera que el tribunal superior realizara un análisis o examen comprensivo e integral de todas las cuestiones debatidas y analizadas en el tribunal inferior. Esta situación conlleva a que los recursos de casación interpuestos por los señores Fernán Vargas Rohrmoser y Mauricio Herrera Ulloa, y por el defensor de éste último y apoderado especial del periódico "La Nación”, respectivamente (supra párr. 95. w), contra la sentencia condenatoria, no satisficieron los requisitos del artículo $8.2 \mathrm{~h}$. de la Convención Americana en cuanto no permitieron un examen integral sino limitado. (Subrayado nuestro)

\section{3.- El derecho a recurrir en el ordenamiento constitucional chileno.}

Conviene ahora realizar un análisis de las normas constitucionales chilenas. En este análisis no debe por supuesto olvidarse la jurisprudencia del Tribunal Constitucional.

El art. $19 \mathrm{~N}^{\circ} 3$ inciso $5^{\circ}$ de la CPR señala que:

\footnotetext{
${ }^{41}$ Ver párrafos 163 y 164, "Herrera Ulloa vs. Costa Rica”.
} 
Toda sentencia de un órgano que ejerza jurisdicción debe fundarse en un proceso previo legalmente tramitado. Corresponderá al legislador establecer siempre las garantías de un procedimiento y una investigación racionales y justos.

La exigencia constitucional hecha al legislador consiste en la necesidad de establecer siempre las garantías de un racional y justo procedimiento (debido proceso), integrado, tal como lo ha entendido la unanimidad de la doctrina, por el derecho de impugnar las resoluciones judiciales.

Según el profesor R. Tavolari esta comprensión que ha transformado al derecho a recurrir en una parte inescindible de la noción del debido proceso, ha tenido manifestaciones en la jurisprudencia y obra de la Corte Suprema. Recuerda en esto el capítulo referido al establecimiento del recurso de apelación respecto de la resolución que resuelve el recurso de protección. ${ }^{42}$

A estas alturas del planteamiento, es útil evocar lo que sostenía el profesor Enrique Evans de la Cuadra en relación con lo dispuesto por el art. $19 \mathrm{~N}^{\circ} 3$ inciso $5^{\circ}$ de la CPR. Señala que para que la "resolución" de una "autoridad" sea válida debe reunir los siguientes requisitos:

2) Que la ley haya establecido un procedimiento y una investigación racionales y justos. Si la ley no lo ha establecido, corresponde que "la autoridad" que va aplicar una sanción o que de alguna u otra manera va a afectar derechos, antes de resolver cumpla con la exigencia constitucional del "racional y justo procedimiento e investigación. Si así no sucede, la sanción aplicada y el acto de autoridad son nulos (art. $7^{\circ}$ de la Constitución) y así debe declararlo la justicia ordinaria. ${ }^{43}$ (Subrayado nuestro)

Según el profesor Evans de la Cuadra, del debate producido en la Comisión de Estudio de la Nueva Constitución (sesiones 101 y 103 de 9 y 16 de enero de 1975, respectivamente) se desprenden los "elementos que constituyen un "racional y justo procedimiento". Entre ellos destaca,

5) La posibilidad de revisión de lo fallado por una instancia superior igualmente imparcial y objetiva. ${ }^{44}$

\footnotetext{
42 Ver también Tavolari, R., ob. citada, p. 40 y 124.

${ }^{43}$ Evans de la Cuadra, Enrique, Los Derechos Constitucionales. Tomo II, Editorial Jurídica de Chile, $3^{\circ}$ edición actualizada, Santiago de Chile, 2004, p.143.

${ }^{44}$ Ibidem, p. 144.
} 
Barrientos - Recurso efectivo contra la sentencia...

El contenido esencial del "debido proceso" también ha sido delimitado por el Tribunal Constitucional chileno En una reciente sentencia recaída en un requerimiento de inaplicabilidad ${ }^{45}$ ha insistido que:

[...] conforme a la doctrina nacional, el derecho a un proceso previo, legalmente tramitado, racional y justo, que la Constitución asegura a todas las personas, debe contemplar las siguientes garantías: la publicidad de los actos jurisdiccionales, el derecho a la acción, el oportuno conocimiento de ella por la parte contraria, el emplazamiento, adecuada asesoría y defensa con abogados, la producción libre de pruebas conforme a la ley, el examen y objeción de la evidencia rendida, la bilateralidad de la audiencia, la facultad de interponer recursos para revisar las sentencias dictadas por tribunales inferiores...(Sentencia TC Roles números 376, 389, 481, entre otras; sentencia CS, 5 diciembre 2001, R.G.J., 258). (Subrayado del autor)

En la misma sentencia, agrega, enseguida:

Que la citada garantía se extiende, sin limitación alguna, al ejercicio de la jurisdicción -esto es, el poder-deber de conocer y resolver cualquier conflicto de carácter jurídico- por cualquier órgano, sin que importe su naturaleza, y se refiere a sentencia no en un sentido restringido, sino como a toda resolución que decide una controversia de relevancia jurídica.

La Constitución prevé la exigibilidad de la garantía a todo proceso, cualquiera sea su forma u oportunidad en que se produce, al exigir su concurrencia "siempre"; se trata de un mandato categórico al legislador, no susceptible de calificación o interpretación.

\section{IV.- Una mirada a la noción de revisión amplia o integral.}

La revisión amplia o integral es un concepto que se ha instalado en diferentes ordenamientos jurídicos, impulsado por los dictámenes y sentencias de los organismos internacionales que se mencionan en la sección anterior.

Como se verá la idea de revisión integral presta un gran servicio al objetivo de este trabajo. Por ello, a continuación, examinaré la operatividad o no de esa tesis ampliatoria del examen jurisdiccional en el sistema procesal chileno, argentino y español.

\footnotetext{
45 Sentencia del Tribunal Constitucional de Chile de 8 de agosto de 2006, sobre recurso de inaplicabilidad interpuesto por el H. Senador Guido Girardi., Rol No 478-2006.
} 
Ello supondrá, necesariamente, un esfuerzo de comparación ${ }^{46}$ que evidenciará que mientras buena parte de los sistemas procesales penales tienden, por imperativo supranacional, a la ampliación de la capacidad de revisión, el nuestro, más por una interpretación restringida de las posibilidades de revisión, que por la existencia de normas que así lo impongan, se inclina por la limitación de los alcances de la inspección en sede de nulidad. Capítulo aparte será la racionalidad empleada por el legislador para contemplar recursos en determinados casos mientras que en otros los niega.

\section{1.- El recurso de nulidad chileno y la posibilidad de una revisión amplia.}

El Código Procesal Penal chileno estableció el recurso de nulidad como medio de impugnación a fin de dar cumplimiento a los tratados internacionales vigentes en nuestro país. De hecho, se afirmó en la discusión parlamentaria que, si bien la CADH no exigía en su art. 8.2.h la existencia de un recurso que permitiese la revisión de los hechos, sí requería un recurso amplio desde el punto de vista del condenado, sin muchas formalidades, que facilitara la revisión por parte del tribunal superior. ${ }^{47}$

No es ocioso recordar que en la tramitación del Proyecto de Código Procesal Penal presentado por el Gobierno se planteó la creación de dos tipos de recursos: el recurso extraordinario y el recurso de casación. El primero, se contemplaba para impugnar sentencias condenatorias dictadas en juicio oral que se apartarán manifiesta y arbitriamente de la prueba rendida en la audiencia. El segundo, en cambio, perseguía la nulidad de la sentencia y/o del juicio oral cuando la sentencia incurriese en infracción de disposición legal o constitucional. Dentro de la infracción de ley, se incluían lo que hoy denominamos "motivos absolutos de nulidad". 48

El Senado reformuló el sistema de recursos creado por la Cámara de Diputados y estableció el recurso de nulidad, incluyéndose la causal del recurso extraordinario en el actual art. 374 letra e) del CPP. Esta reformulación buscaba superar los temores de que, la existencia de un recurso con una causal tan amplia, suscitaba por la posibilidad de abuso en su interposición. Se trataba de evitar que el recurso, en la práctica, se transformase en una apelación encubierta, permitiendo por esa vía que el tribunal superior revisase la valoración de la prueba, con el

\footnotetext{
${ }^{46} \mathrm{M}$. Taruffo postula el empleo sistemático de la comparación como método de análisis y de confrontación de las líneas de evolución de los diversos sistemas procesales y como instrumento para formular y hacer circular informaciones y posibles soluciones en relación con los problemas que enfrenta un sistema. Taruffo, Michele, "Racionalidad y Crisis de la Ley Procesal", Doxa $N^{\circ} 22$, 1999, p. 311-320.

${ }^{47}$ Segundo Informe de la Comisión de Constitución, Legislación, Justicia y Reglamento del Senado, citado en Maturana M., Cristián, ob. citada, p. 110.

48 Ver: Pfeffer U., Emilio, Código Procesal Penal. Anotado y Concordado, Editorial Jurídica de Chile, $1^{\circ}$ edición, Santiago de Chile, p. 367-371, y; Maturana M., Cristián, ob. citada, p. 9-150.
} 
Barrientos - Recurso efectivo contra la sentencia...

seguro quiebre de los principios de inmediación y oralidad, pues la tarea de valorar se encomendaba al tribunal de mérito. ${ }^{49}$

La creación del recurso de nulidad, dejando atrás la denominación de casación, persiguió no sólo un cambio cosmético, pues si bien se escucharon referencias a la intangibilidad de los hechos establecidos por el tribunal oral, también se razonó en torno a la existencia, en cualquiera control legal de las sentencias, de problemas límites relacionados con los hechos. Es así como se recordó que, no obstante la vigencia en varios países de la Europa continental de recursos de casación clásicos, en cuanto se ocupan sólo de controlar el apego de los tribunales a los criterios dictados por el legislador,

[...] los tribunales han entrado en la consideración de elementos de hechos, por la vía de estimar, por ejemplo, que se vulnera la presunción de inocencia en cuanto la prueba no es suficiente. ${ }^{50}$

Por ello, más allá de las posibles discusiones, creo que de la historia del establecimiento de CPP y de la finalidad del motivo absoluto de la letra e) del art. 374, podemos plantear que la revisión, si bien restringida, en principio, a aquello que suele llamarse cuestiones de derecho, tiene un margen de amplitud que asegura la justicia del caso concreto. En primer lugar, se puede lograr ese objetivo, por la vía de la nulidad del juicio oral y la sentencia por infracción a la presunción de inocencia como garantía constitucional, lo que supone necesariamente ocuparse de los hechos y de las pruebas rendidas cuando esa infracción sea sustancial e influyente en lo dispositivo del fallo. ${ }^{51}$ En segundo lugar, mediante el control a los límites a la libre valoración de la prueba (principios de la lógica, las máximas de la experiencia y los conocimientos científicamente afianzados) en que el tribunal superior puede y debe controlar la relación lógica entre esa valoración y las conclusiones a la que llegan en su fallo los jueces de mérito. ${ }^{52}$

Con todo, la jurisprudencia de los tribunales superiores, apoyada sólo en parte de la historia legislativa, parece muy lejana de un examen integral de la sentencia. En principio, podría sostenerse que la lógica de la Corte Suprema y de las diversas Cortes de Apelaciones, es del mínimo esfuerzo revisor, como lo

\footnotetext{
${ }^{49}$ Segundo Informe de la Comisión de Constitución, Legislación, Justicia y Reglamento del Senado, citado en Maturana M., Cristián, ob. citada, p. 95.

${ }^{50}$ Maturana M., C., ob. citada, p. 79. Ver, en el mismo texto, la opinión de profesor Magalháes, p.83.

${ }^{51}$ Una demostración de que ello es jurídicamente sostenible es lo ocurrido en España, país en el que el Tribunal Constitucional ha afirmado que "mediante la alegación como motivo de casación de la infracción del derecho a la presunción de inocencia, el recurrente puede cuestionar, no sólo el cumplimiento de las garantías legales y constitucionales de la prueba practicada, sino la declaración de culpabilidad que el Juzgador de instancia dedujo de su contenido". Al respecto se puede consultar entre otras la STC 341/2005.

52 Siguiendo la expresión de Bacigalupo, Enrique, en "Doble instancia y principio de inmediación", Derecho Penal y el Estado de Derecho, p. 266, el recurso de nulidad chileno sería una "casación ampliada".
} 
demuestran las reiteradas resoluciones, de la primera, sobre remisión de recursos a las Cortes de Apelaciones ${ }^{53}$ y, de todas las Cortes, sobre admisibilidad/improcedencia del recurso de nulidad, especialmente en relación a beneficios de la Ley $\mathrm{N}^{\circ} 18.216 .{ }^{54}$

La afirmación que el funcionamiento del sistema de recursos contemplados en el CPP está lejos de satisfacer los requerimientos de los organismos internacionales no carece de todo asidero. Existe numerosa jurisprudencia de nuestros tribunales superiores que clausuran, en la práctica, el análisis del recurso de nulidad declarando que se trata de un medio de impugnación de derecho estricto y que las cortes están limitadas exclusivamente al examen de los aspectos jurídicos de la sentencia y que no pueden revisar los hechos de la causa ni valorar la prueba rendida, por ser esta atribución exclusiva de los jueces del fondo. ${ }^{55}$

El mínimo esfuerzo revisor se impone como una realidad en el sistema procesal penal al alero de la idea de la intangibilidad de los hechos del juicio oral. Sin embargo, se trata sólo de una regla general, ya que por la vía de velar por la fundamentación de las sentencias, incluso la Corte Suprema ha analizado la prueba rendida en el juicio en aquella parte que ha sido objetada por el recurrente. Así lo hizo en sentencia dictada el 12 de mayo de 2003 en causa RUC 0100058837, (Rol CS N ${ }^{\circ}$ 964-03). En dicha resolución señaló que en la medida que el artículo 342, en relación con el artículo 297 del CPP, reglamenta la forma cómo los jueces deben dar por acreditados los hechos, esa norma autoriza la anulación del fallo si no son respetadas. ${ }^{56}$ Sin embargo, fiel a su doctrina, agrega a renglón seguido, que

\footnotetext{
${ }^{53} \mathrm{El}$ siguiente es el desglose del resultado de los recursos interpuestos para ante la Corte Suprema durante año el año 2007. Recursos de Nulidad interpuestos por la Defensoría: 69. Acogido 3; Rechazado 14; Inadmisible 5; Inadmisible y Remitido 6; Remitido 40; Pendiente 1; Recursos de nulidad interpuestos por defensa privada: 142. Acogido 1; Rechazado 5; Desistido 1; Abandono 1; Remitido 70; Inadmisible 46; Inadmisible y remitido 17; Pendiente 1; Recursos de nulidad interpuestos por el Ministerio Público: 8. Desistido 2; Acogido 4; Remitido 2. Fuente: Unidad de Corte, Defensoría Nacional, Defensoría Penal Pública.

${ }^{54}$ Ver cita $n^{\circ} 8$.

${ }^{55}$ Entre las sentencias que podemos mencionar están las siguientes: Corte Suprema: 30 de mayo de 2005, Rol 4656-05; Cortes de Apelaciones: Pto. Montt, 25 de junio de 2007, Rol N 136-07; Antofagasta, 14 de febrero de 2006, Rol N²08-906; Chillán, 20 de abril de 2007, Rol № 30-07; San Miguel, 27 de marzo de 2006, Rol N 110-06; Iquique, 9 de febrero de 2007, Rol N 187-2006; Rancagua, 4 de julio de 2006 y 13 de marzo de 2007, Rol 151-06 y Rol ํ51-07, respectivamente; Punta Arenas, 21 de julio de 2006, Rol No 82-06; Temuco, 11 de julio de 2006, Rol N 603-06; Santiago, 10 de diciembre de 2007, Rol N²500-07; La Serena, 13 de febrero de 2007, Rol No $7 / 07$.

56 Otras sentencias en que, sin perjuicio de la intangibilidad de los hechos establecidos en el juicio oral, por la vía de velar por la correcta fundamentación de las sentencias, la Corte de Apelaciones de Antofagasta se ve obligada a revisar el razonamiento jurídico y, con ello, las pruebas empleadas para construir ese razonamiento, son las dictadas en causa Rol 186-2006, de catorce de noviembre de dos mil seis y en causa Rol No 12-2008, de 19 de febrero de 2008. Lo importante de estas sentencias es que en ambos casos se acoge el recurso de nulidad interpuesto por la defensa y en el nuevo juicio los imputados son absueltos.
} 
Barrientos - Recurso efectivo contra la sentencia...

en ningún caso implica un control del tribunal ad quem sobre los hechos, sino sobre el cómo llegaron a ellos los jueces del tribunal oral.

Deberá ser la experiencia forense, pues no existe ningún impedimento textual, la que nos deberá conducir a una interpretación más progresiva del alcance del recurso de nulidad que, aplicando las normas internacionales vigentes nos ponga de lleno en la senda de una revisión judicial que, sin medrar los principios básicos del juicio oral, armonice con la necesidad de entregar satisfacción y protección en sus derechos fundamentales a quienes se sienten perjudicados con una resolución judicial. Esa es, sin duda, una tarea en la que estamos por ahora, parcialmente, remisos.

Lo importante para el objetivo de este trabajo es que la lógica del sistema de recursos del CPP es la centralidad del juicio oral y, con ello, la inmediación, evitando entregar la decisión final sobre la valoración de la prueba a jueces que no están en condiciones de apreciar en forma directa la prueba rendida en la audiencia de juicio oral. Dicho de un modo simple, la razón de la clausura legal de la impugnación está fundada en el principio de inmediación.

En cambio, la clausura judicial de la impugnación de las sentencias condenatorias que no conceden beneficios de la Ley $\mathrm{N}^{\circ} 18.216$ está basada en otras razones. Los argumentos han sido más banales: el carácter de derecho estricto del recurso de nulidad y la negación del carácter de sentencia definitiva de aquella parte de la jsentencia definitiva! que se refiere a los beneficios.

\section{2.- La revisión integral en la jurisprudencia y doctrina argentina.}

La idea de una revisión amplia o integral de la sentencia recurrida es una cuestión que ha sido objeto de mucho análisis en Argentina. Las preguntas que se han planteado los procesalistas argentinos es: ¿Cuál es el objeto sobre el que debe recaer la revisión? ¿Qué es lo revisable de un fallo?

En el análisis de la jurisprudencia y doctrina argentina sólo tendremos en cuenta el objetivo de nuestro trabajo y podremos hacernos cargo de algunos de los argumentos que definen la noción de revisión integral. ${ }^{57}$

\footnotetext{
${ }^{57}$ El Código Procesal Penal de la Nación Argentina, señala en el art. 456: "El recurso de casación podrá ser interpuesto por los siguientes motivos: $1^{\circ}$ ) Inobservancia o errónea aplicación de la ley sustantiva. $2^{\circ}$ ) Inobservancia de las normas que este Código establece bajo pena de inadmisibilidad, caducidad o nulidad, siempre que, con excepción de los casos de nulidad absoluta, el recurrente haya reclamado oportunamente la subsanación del defecto, si era posible, o hecho protesta de recurrir en casación”. A su vez, el art. 457 indica que "Además de los casos especialmente previstos por la ley y con las limitaciones establecidas en los artículos siguientes, podrá deducirse este recurso contra las sentencias definitivas y los autos que pongan fin a la acción o a la pena, o hagan imposible que continúen las actuaciones o denieguen la extinción, conmutación o suspensión de la pena".
} 
El episodio que marcó la preocupación actual por la revisión integral es la adopción, por la Corte Suprema argentina, del fallo "Casal" de 20 de septiembre de $2005 .^{58}$ En esta sentencia el tribunal trasandino se valió de la teoría alemana de la Leistungsfäbigkeit ${ }^{9}$, la que, según la Corte argentina, propone que el tribunal de casación debe agotar el esfuerzo por revisar todo lo que pueda revisar, o sea, por agotar la revisión de lo revisable. Este agotamiento de las capacidades de revisión implica que el tribunal de casación está obligado a revisar todo lo que le sea posible, quedando solamente excluidas las cuestiones directamente relacionadas al principio de inmediación. ${ }^{60}$

Los jueces argentinos ${ }^{61}$ en su fallo, con claras alusiones a la jurisprudencia de la CIDH y del Comité de Derechos Humanos, se ocupan de la idea de incompatibilidad de la doble instancia con la inmediación del plenario oral. $\mathrm{La}$ principal pregunta que formula la Corte es: ¿Qué es lo no revisable por el tribunal superior? Su respuesta, que intenta compatibilizar el derecho a recurrir con la garantía de la inmediación, no se deja esperar: lo único no revisable es lo que surja directa y únicamente de la inmediación.

En ese intento de compatibilización, la Corte promueve una interpretación armónica de los derechos y garantías establecidos en la Constitución Federal ${ }^{62}$, en

\footnotetext{
${ }^{58}$ Se debe aclarar en todo caso que el primer fallo que sentó un precedente importante postulando una revisión amplia fue el dictado por la Cámara Nacional de Casación Penal un año antes del fallo “Casal”, en expediente C. 4807 "López, Fernando Daniel s/recurso de queja”, Sala IV, 15/10/2004. Con posterioridad a "Casal" la Corte Suprema ha reiterado su posición ampliatoria de la inspección casacional en "Martinez. Areco, Ernesto", (sentencia de 25 de octubre de 2005, causa No 3792/2005) y "Beloso, Nicolás Alberto" (sentencia de 28 de marzo de 2006, causa $\left.\mathrm{N}^{\circ} 1281 / 2006\right)$.

${ }^{59}$ El fallo "Casal” recurre, para apoyar su decisión, a la teoría alemana de la Leistungsfäbigkeit, esto es, el agotamiento de la capacidad de revisión. Según la misma sentencia Leistung es el resultado de un esfuerzo y Fähigkeit es capacidad, por lo que la expresión se ha traducido también como capacidad de rendimiento. Para una lectura que suministre mayor información acerca de los orígenes y verdaderos efectos de la teoría invocada por la Corte trasandina se puede consultar el lúcido trabajo de Pérez Barberá, Gabriel, titulado "Casación penal y posibilidad de control. Alcance del fallo "Casal" y del método alemán invocado por la Corte", Suplemento de Administración de Justicia, El Dial, $15 / 05 / 2007$.

60 Tras el fallo "Casal" existen dos proyectos de ley, en el Congreso argentino, que buscan modificar la regulación del recurso de casación para adecuarlo a la nueva doctrina de la Corte Suprema. El primero, es de 18 de octubre de 2006 presentado por varios diputados (expediente $\mathrm{N}^{\circ}$ 6174-D-2006). El otro, presentado por el diputado José Cafferata Nores, el 2 de agosto de 2007, como consecuencia de un proceso de solución amistosa entre 21 peticionarios y el Estado argentino ante la Comisión Interamericana de Derechos Humanos.

${ }^{61} \mathrm{La}$ Corte Suprema argentina estaba integrada al momento de la emisión del fallo por los magistrados Enrique Petracchi, Juan Carlos Maqueda, Raúl Zaffaroni, Ricardo Lorenzetti, Elena Higton de Nolasco, Carmen Argibay y Carlos Fayt.

${ }^{62} \mathrm{El}$ art. art. 75 de la Constitución Política argentina establece que corresponde al Congreso: "22. Aprobar o desechar tratados concluidos con las demás naciones y con las organizaciones internacionales y los concordatos con la Santa Sede. Los tratados y concordatos tienen jerarquía superior a las leyes.[...]La Declaración Americana de los Derechos y Deberes del Hombre; la Declaración Universal de Derechos Humanos; la Convención Americana sobre Derechos
} 
Barrientos - Recurso efectivo contra la sentencia...

los Tratados internacionales y en el Código Procesal Penal argentino, de tal forma que ningún precepto constitucional o de rango constitucional actúe como cancelatorio de otro. Esta afirmación deriva de la idea que entre la inmediación, consustancial al juicio oral, y la revisión amplia en casación no existe incompatibilidad real. Los siguientes párrafos sirven para comprender cabalmente el aserto del máximo tribunal argentino:

24) Que formulada esta teoría, se impone preguntar qué es lo no revisable. Conforme a lo expuesto, lo único no revisable es lo que surja directa y únicamente de la inmediación. Esto es así porque se imponen limitaciones de conocimiento en el plano de las posibilidades reales y —en el nivel jurídico- porque la propia Constitución no puede interpretarse en forma contradictoria, o sea, que el principio republicano de gobierno impide entender un dispositivo constitucional como cancelatorio de otro. En este caso son los textos de la Convención Americana y del Pacto Internacional que no pueden ser interpretados en forma contradictoria: en efecto, los arts. 8.5 de la Convención Americana y 14.1 del Pacto exigen la publicidad del juicio, con lo cual están exigiendo la oralidad, que es inseparable condición de la anterior, y, por ende, no puede entenderse que los arts. 8.2.h. de la Convención Americana y 14.5 del Pacto impongan un requisito que la cancela. Por ende, debe interpretarse que los arts. 8.2.h de la Convención y 14.5 del Pacto exigen la revisión de todo aquello que no esté exclusivamente reservado a quienes hayan estado presentes como jueces en el juicio oral. [...]

En "Casal" la Corte argentina no sólo efectúa un acucioso estudio del derecho al recurso, sino que emite un mandato que debe ser acatado por los tribunales de casación. Exige, la Corte, valiéndose de la teoría de la máxima capacidad de rendimiento, que el tribunal competente en materia de casación agote su capacidad revisora conforme a las posibilidades y particularidades de cada caso, revisando todo lo que le sea posible revisar y archivando la impracticable

\footnotetext{
Humanos; el Pacto Internacional de Derechos Económicos, Sociales y Culturales; el Pacto Internacional de Derechos Civiles y Políticos y su Protocolo Facultativo; la Convención sobre la Prevención y la Sanción del Delito de Genocidio; la Convención Internacional sobre la Eliminación de todas las Formas de Discriminación Racial; la Convención sobre la Eliminación de todas las Formas de Discriminación contra la Mujer; la Convención contra la Tortura y otros Tratos o Penas Crueles, Inhumanos o Degradantes; la Convención sobre los Derechos del Niño; en las condiciones de su vigencia, tienen jerarquía constitucional, no derogan artículo alguno de la primera parte de esta Constitución y deben entenderse complementarios de los derechos y garantías por ella reconocidos. Sólo podrán ser denunciados, en su caso, por el Poder Ejecutivo nacional, previa aprobación de las dos terceras partes de la totalidad de los miembros de cada Cámara. [...] Los demás tratados y convenciones sobre derechos humanos, luego de ser aprobados por el Congreso, requerirán del voto de las dos terceras partes de la totalidad de los miembros de cada Cámara para gozar de la jerarquía constitucional."
} 
distinción entre cuestiones de hecho y de derecho, como la única forma de lograr un entendimiento de la ley procesal penal vigente acorde con las exigencias de la Constitución Nacional y de la jurisprudencia internacional. El máximo esfuerzo de revisión que se pide, puede y debe hacerse, según la Corte, siempre que no se magnifique las cuestiones reservadas a la inmediación y que se prefiera una interpretación amplia de la facultad recursiva, como la única compatible con lo dispuesto por la Constitución Nacional y los estándares internacionales. ${ }^{63}$

Después de "Casal", la ampliación de la sede casacional en el país vecino se proyecta como una consecuencia del mandato de máxima revisión posible, según las particularidades de cada caso; de la minimización de los efectos limitadores de la inmediación, y; de la necesidad de conciliar los mandatos constitucionales, evitando sacrificios o cancelaciones inútiles.

Fernando Díaz Cantón comentando el fallo "Casal" sostiene que la Corte Suprema, invocando la garantía fundamental del imputado de recurrir del fallo condenatorio, ha establecido los siguientes nuevos patrones respecto del recurso de casación:

a) Permitir el examen sencillo y sin rigores formalistas de la validez de la sentencia condenatoria recurrida en general.

b) Posibilitar la revisión de la aplicación de las reglas sobre la prueba en el caso concreto.

c) Garantizar un examen integral de la decisión recurrida (cuestiones de hecho y prueba). ${ }^{64}$

Sin perjuicio de la importancia del fallo "Casal", no es posible desconocer que la doctrina argentina venía, desde hacía tiempo, planteando la necesidad de una reforma del recurso de casación y, concretamente, su ampliación. Julio Maier, abogaba ya en 1996 por la necesidad de "ordinarizar" el recurso de casación y ampliar su objeto, aunque eso implicara extraerlo de su contexto tradicional, pues, en su opinión, era la única forma de responder a la cláusula de garantía. ${ }^{65}$ Alberto

\footnotetext{
63 Sugiero al lector revisar el Considerando 25 del Fallo Casal. Por su parte, la Sala Penal del Tribunal Superior de Justicia de la Provincia de Chubut, en sentencia dictada en causa Garcia, Nestor Fabián y otros/robo agravado, (expediente. 20354-195-2006), resolvió, conociendo de un recurso de casación, que: "Debe quedar claro que la doctrina sentada por la Corte Federal el 20 de septiembre de 2005, en autos: C.1757 XL. 'Casal, Matías Eugenio y otros s/robo simple en grado de tentativa...', [...] al imponer una integral revisión no ha hecho otra cosa que ordinarizar el recurso, en razón de lo cual el requisito de autosustentación o exhaustividad, desaparece dando paso a una simple y clara exposición de los agravios tal como si se tratara de un simple recurso de apelación."

${ }^{64}$ Díaz Cantón, Fernando, "La Relación Entre el Recurso de Casación Penal y el Recurso Extraordinario Federal: Panorama y Prospección”, Suplemento Penal de El Dial.com, Editorial Albrematica (El Dial DC9E4). en: www.procesal2007mdp.com.ar/resource/Díaz\%20Cantón\%20(Congreso\%20procesal\%202007).d oc

${ }^{65}$ Maier, J. B., ob. citada, p. 705-726.
} 
Barrientos - Recurso efectivo contra la sentencia...

Binder sostenía en 1993 que era hora de abandonar una visión esencialista acerca de los recursos y postulaba que el desafío era establecer un recurso que impusiese el máximo control posible, con el máximo respeto a los principios y garantías procesales, en especial al principio de inmediación. ${ }^{66}$ En la misma dirección apuntaba Daniel Pastor, en 2001, cuando planteaba que el recurso contra la sentencia condenatoria, para ser eficaz, debía ser tan amplio como los demás principios de garantía judicial de los derechos fundamentales lo permitiesen y, en concreto, afirmaba que la inmediación no podía ser un límite para una reprobación amplia de los defectos de la sentencia condenatoria. ${ }^{67}$ Por último, el ya citado Díaz Cantón, en una obra de 2005, previa a "Casal", expresaba que lo importante no era la distinción entre cuestiones de hecho y de derecho, o de valoración de las pruebas y de derecho, sino que la determinación del ámbito de la inspección casacional, por la vía de distinguir lo que depende del conocimiento exclusivo de los jueces del juicio y lo que no. ${ }^{68}$

Habiendo trazado las principales ideas de la tesis ampliatoria de la revisión judicial, ahora me interesa relevar la aplicación de la noción de revisión integral respecto de la impugnación de la sentencia en aquella parte relativa, ya no a la declaración de culpabilidad, sino a la pena.

La Cámara Nacional de Casación Penal, valiéndose precisamente de una noción no explicitada de revisión integral, fue paulatinamente ampliando su competencia hasta llegar a entender en cuestiones de ejecución de la pena. Fue así como la Cámara comenzó a conocer recursos relacionados con la libertad condicional, la revocación de ésta, al cómputo de penas y medidas de seguridad, dejando inicialmente fuera del ámbito casacional las decisiones sobre libertad asistida, detención domiciliaria, salidas transitorias, semilibertad, prisión discontinua, las que, en su opinión, debían ser conocidas por el juez de ejecución. Posteriormente, dictó sentencias que ampliaron su competencia hasta abordar cuestiones concernientes a la libertad asistida.

En 1998 en el caso "Fuentes" ", donde se cuestionaba la denegatoria de las salidas transitorias, en voto de minoría el juez Gustavo Hornos señaló:

\footnotetext{
${ }^{66}$ Binder, A., ob. citada, p. 289-290.

${ }^{67}$ Pastor, Daniel, La nueva imagen de la Casación penal. Evolución histórica y futuro de la dogmática de la impugnación en el derecho procesal penal, Ed. Ad-Hoc, Buenos Aires, 2001.

${ }^{68}$ Díaz Cantón, Fernando, en "La casación penal en la provincia de Buenos Aíres", La motivación de la sentencia penal y otros estudios, Editores del Puerto, Buenos Aires, $1^{\circ}$ edición, 2005, p. 152.

${ }^{69}$ Sentencia de 26 de febrero de 1998, Fuentes, Juan Carlos s/ recurso de casación, Causa No 742-1998.
} 
[...] El Código Procesal Penal de la Nación en el artículo $491^{70}$ fija con claridad la existencia del recurso de casación respecto de las decisiones de dichos magistrados. Disposición que es la que mejor concuerda con el espíritu garantista que concordantemente las normas citadas han tenido en miras. También en estas circunstancias y dados los intereses en juego, resulta la doble instancia judicial la forma adecuada para el mejor resguardo de los derechos de los sometidos a pena privativa de la libertad; y es la que mejor se adecua al principio plasmado por la Convención Americana sobre Derechos Humanos que asegura, como garantía mínima, el derecho a recurrir ante un tribunal superior (art. $8^{\circ}$, ap. 2 , inc. h).

En el caso "Quispe Ramírez"71, donde se deniega al condenado su incorporación al régimen de semilibertad, se impone en la CNCP la tesis del juez Hornos, y se repite la argumentación vertida en "Fuentes".

Por su parte, en 2004 la Corte Suprema argentina en el caso "Romero Cacharane" "72 le otorgó competencia a la Cámara Nacional de Casación Penal, sobre cuestiones de ejecución penal. En este caso la defensa del condenado apeló de una sanción de aislamiento ante el juez de ejecución penal, el que rechazó el recurso interpuesto. Ante esto el abogado del condenado, apoyado en el art. 491 del CPP, formalizó recurso de casación. La Sala II de la CNCP declaró inadmisible el recurso. El defensor insistió por la vía del recurso extraordinario ante el máximo tribunal, invocando la violación del derecho contemplado en el art. 8.2.h de la $\mathrm{CADH}$, el que acogió su pretensión.

La Corte Suprema, además de insistir en que la pretendida diferencia entre cuestiones administrativas y jurídicas relacionada con la ejecución de la pena responde a una concepción anacrónica, sostiene, fundado en la intención del legislador y en la garantía del derecho al recurso, que:

21) Que, por otra parte, cabe tener presente que el recurso de casación es un instrumento operativo de la garantía prevista en el inc. h del punto 2 del art. 8 de la Convención Americana sobre Derechos Humanos. En efecto, la Comisión Interamericana ha señalado que un aspecto esencial derivado del debido proceso es

\footnotetext{
70 El Art. 491 del Código Procesal Penal argentino establece que: "Los incidentes de ejecución podrán ser planteados por el ministerio fiscal, el interesado o su defensor y serán resueltos previa vista a la parte contraria, en el término de cinco (5) días. La parte querellante no tendrá intervención. Contra la resolución sólo procederá el recurso de casación, pero éste no suspenderá la ejecución a menos que así lo disponga el tribunal."

${ }^{71}$ Sentencia de 18 de junio de 1999, Quispe Ramirez, Inocencio s/recurso de casación, Causa $\mathrm{N}^{\circ} 1367$ 1999.

${ }^{72}$ Sentencia de 9 de marzo de 2004, Romero Cacharane, Hugo Alberto s/ejecución penal, R. 230. XXXIV.
} 
Barrientos - Recurso efectivo contra la sentencia...

el derecho a que un tribunal superior examine o reexamine la legalidad de toda sentencia jurisdiccional que resulte en un gravamen irreparable a una persona, o cuando ese gravamen afecte los derechos y libertades fundamentales. También agregó que "el derecho previsto en el artículo 8.2.h requiere la disponibilidad de un recurso que al menos permita la revisión legal, por un tribunal superior, del fallo y de todos los autos procesales importantes. (Subrayado original)

Para los efectos de nuestro trabajo, y especialmente para criticar la reiterada jurisprudencia de nuestros tribunales superiores sobre el carácter de las resoluciones que se refieren a los beneficios, es importante destacar el voto particular del ministro Carlos Fayt, quien refiriéndose a la naturaleza jurídica de las resoluciones en sede de ejecución penal, expresa que

[...] construir el sistema de recurso en la etapa de ejecución examinando una pretendida "naturaleza jurídica" de los distintos tipos de resoluciones carece de toda fundamentación. La distinción entre decisiones que hacen al "título ejecutivo de la condena" o cuestiones "netamente jurídicas" -como aquellas pasibles de ser casadas- por un lado y "reglamentarias" -no pasibles de ser recurridas en casación- por otro, es meramente dogmática y carente de sustento legal, toda vez que el a quo no determina sobre qué base elabora la clasificación adoptada.

Tras el fallo "Romero Cacharane", la Sala IV de la CNCP despachó en julio de 2005, en el caso "Merli" "73 una resolución que recoge la tesis del máximo tribunal. Especial mención merece el voto del juez Hornos, quien antes del fallo "Casal", afirmaba rotundamente que

He sostenido con insistencia que el control judicial amplio y eficiente resulta un factor altamente positivo para el logro de los fines que procuran las normas de ejecución de las penas privativas de libertad.

\section{3.- La revisión integral en la jurisprudencia española.}

En cuanto al acceso al recurso en el ordenamiento español, es necesario considerar, por un lado, el art. 24. 1 y 2 de la Constitución Española de 1978 y, por otro, la jurisprudencia del Tribunal Constitucional y del Tribunal Supremo.

El art. 24 de la Constitución Española dispone que:

\footnotetext{
${ }^{73}$ Sentencia de 22 de julio de 2005, Merli, Jorge Nelson s/ recurso de casación, Causa № 5317-2005.
} 
1. Todas las personas tienen derecho a obtener la tutela efectiva de los jueces y tribunales en el ejercicio de sus derechos e intereses legítimos, sin que, en ningún caso, pueda producirse indefensión.

2. Asimismo, todos tienen derecho al juez ordinario predeterminado por la ley, a la defensa y a la asistencia de letrado, a ser informado de la acusación formulada contra ellos, a un proceso público sin dilaciones indebidas y con todas las garantías, a utilizar los medios de prueba pertinentes para su defensa, a no declarar contra sí mismos, a no confesarse culpables y a la presunción de inocencia.

Existe relativo acuerdo en que el numeral 1 del art. 24 contempla el llamado derecho a la tutela judicial efectiva, mientras que el numeral 2 establece lo que propiamente llamamos debido proceso o proceso justo ("proceso con todas las garantías"). En cuanto a la naturaleza y a la forma de articular ambos derechos no existe, en cambio, consenso, siendo una cuestión controvertida en la doctrina española. En todo caso, lo relevante es que, desde la perspectiva del ordenamiento español, el debate acerca del acceso a los recursos puede ser analizado considerando el sistema de derechos de la Constitución Española de 1978 y la copiosa jurisprudencia del Tribunal Constitucional sobre el derecho a la tutela judicial efectiva, sin perjuicio de la relación entre este derecho y el debido proceso de origen anglosajón.

El Tribunal Constitucional ha sostenido de manera reiterada que el acceso al recurso es una de las múltiples manifestaciones del derecho a la tutela judicial efectiva, insistiendo en que los requisitos establecidos en las leyes para su admisión han de ser interpretados de la forma en que resulte más favorable para la efectividad del derecho fundamental. Asimismo, ha afirmado que el Pacto, si bien no es suficientemente imperativo para crear por sí mismo recursos inexistentes, obliga a considerar que entre las garantías derivadas del art. 24 de la Constitución española se encuentra la del recurso ante un tribunal superior. ${ }^{74}$

En diversas sentencias, el Tribunal Constitucional dejó, inicialmente, entrever que el art. 24.1 obligaba al legislador en materia penal, a diferencia de otro tipo de jurisdicciones, a establecer la doble instancia. ${ }^{75}$

Sin embargo, la posterior jurisprudencia del Tribunal Constitucional, en un principio vacilante, modificó el criterio anterior, señalando que el 24.1, en relación con el art. 14.5 del Pacto, no obligaba al establecimiento de la doble instancia, sino

\footnotetext{
${ }^{74}$ STC 366/81; STC 57/82, y; STC 76/82.

75 Ver: STC 157/89 y STC 374/93. El Tribunal Constitucional se pronunció, en similares términos, en STC $61 / 83$ y $58 / 87$.
} 
Barrientos - Recurso efectivo contra la sentencia...

que solo al sometimiento del fallo a la revisión por parte de un tribunal superior. ${ }^{76}$ Así, asevera hasta hoy que lo obligatorio de acuerdo al Pacto no es

[...] propiamente una "doble instancia", sino una sumisión del fallo condenatorio y de la pena a un "Tribunal superior", sumisión que habrá de ser conforme "a lo prescrito por la Ley", por lo que ésta en cada país fijará sus modalidades. ${ }^{77}$

Para comprender la evolución del ámbito de la casación es útil analizar la doctrina original del Tribunal Supremo de España, aquella que provocó la queja ante el Comité de Derechos Humanos. Esta se encuentra resumida en la sentencia de 9 de noviembre de 1993, que da origen a unos de los pronunciamientos del Comité, y en que el Tribunal Supremo afirmó que:

[...] el recurrente, por tanto, reconoce la existencia de múltiples pruebas de cargo y sus razonamientos únicamente se concretan en interpretarlas a su modo y manera, dialéctica impermisible cuando se alega este principio de presunción de inocencia, pues si tal se aceptase sería tanto como desnaturalizar el recurso de casación convirtiéndolo en una segunda instancia. ${ }^{78}$

Agrega, a continuación que:

[...] aunque lo verdaderamente pretendido sea la aplicación del principio in dubio pro reo, la solución desestimatoria es la misma, pues olvida la parte recurrente que este principio no puede tener acceso a la casación por la razón obvia que, [...] nos es impermisible. $^{79}$

Después de esta sentencia del Tribunal Supremo, España resultó condenada por el Comité. No obstante, es precisamente a partir de este momento que se promueve una creciente preocupación jurisprudencial por el tema, centrando la discusión acerca de lo que realmente exige el PIDCP en materia recursiva.

Desde el 2000 se puede apreciar una interesante evolución, tanto en el Comité de Derechos Humanos como en los tribunales españoles. Por un lado, el Comité moderó las exigencias a los estados respecto de lo que debe entenderse por "revisión por un tribunal superior". Por otro, España, a través de sus tribunales,

\footnotetext{
${ }^{76}$ STC $76 / 82$.

77 Ibídem.

78 STS 3.766, de 9 de noviembre de 1993, C/ Cesáreo Gómez V.

79 Ibidem. Consultar sobre la relación entre in dubio pro reo y recurso de casación: Bacigalupo, Enrique, "Presunción de inocencia, in dubio pro reo y recurso de casación, Derecho Penaly el Estado de Derecho, Editorial Jurídica de Chile, Santiago de Chile, 2005, pp. 183-210.
} 
acogió las indicaciones del Comité en orden a una interpretación menos formalista de la casación y a la ampliación de la revisión judicial a cuestiones fácticas. A su vez, la posibilidad de invocar como motivo de casación la infracción de un precepto constitucional, desde la vigencia del nuevo artículo 852 de la Ley de Enjuiciamiento Criminal ${ }^{80}$, ha dado un impulso mayor a esta tendencia.

Así, por ejemplo, en septiembre de 2000, con posterioridad al primero de los dictámenes contra España, el Tribunal Supremo, en una clara señal aperturista de la casación, expresó que:

En trámite de casación, al alegarse la vulneración de la presunción de inocencia, la Sala del Supremo deberá ponderar: a) las pruebas que tuvo en cuenta el Tribunal de instancia para atribuir unos hechos delictivos a una persona; b) si las pruebas fueron practicadas en el juicio con sujeción a los principios de oralidad, inmediación, contradicción y publicidad; c) si de haber sido practicadas en el sumario, fueron introducidas en el debate del plenario por la vía de los arts. 714 y 730 LECrim.; d) si las pruebas se practicaron con observancia de las normas procesales y respeto a los derechos fundamentales; e) si las conclusiones probatorias del Tribunal sentenciador no contravienen las leyes de la lógica, de la experiencia o de las ciencia. ${ }^{81}$

También el Tribunal Constitucional se ha referido al alcance de la casación. Dos sentencias son las más importantes sobre este punto. La STC 70/2002 (3 de abril de 2002) y la STC 116/2006 (24 de abril de 2006). La primera, sostuvo originalmente la asimilación funcional entre el recurso de casación y el derecho de revisión de la culpabilidad y la pena siempre:

\footnotetext{
${ }^{80} \mathrm{El}$ nuevo artículo 852 de la Ley de Enjuiciamiento Criminal expresa que: "En todo caso, el recurso de casación podrá interponerse fundándose en la infracción de precepto constitucional". El art. 5.4 de la Ley Orgánica del Poder Judicial admitía antes mucho del 1993 (año del caso Gómez Vásquez, v. España) la posibilidad de alegar, como fundamento del recurso de casación, en todos los casos en que proceda según la ley, la infracción de precepto constitucional. Antes de la incorporación de este artículo el Tribunal Constitucional en varias sentencias había señalado que la presunción de inocencia, como derecho constitucional, podría ser aducida para fundamentar un recurso de casación, por el cauce del art. 849.2 de la Ley de Enjuiciamiento Criminal. Se puede ver: STC 56/82, 140/85 y 57/86. Al efecto se puede consultar Aparicio Calvo-Rubio, José, "Protección Constitucional al Recurso en el Proceso Penal", Revista Española de Derecho Constitucional, año 8, N 22, enero-abril, 1988, pp. 245 y 247.

${ }^{81}$ STS de 4 de septiembre de 2000. Al respecto también se puede consultar las: STS de 3-1-01 en que se analiza la declaración del testigo único; STS de 22 de diciembre de 2000 en que alegada la insuficiente acreditación de una falta de vejaciones leves, el tribunal especifica cuáles son las declaraciones que acreditan los improperios lanzados por el acusado; la STS de 16 de febrero de 2001 en una condena por delito fiscal; la STS de 3 de abril de 2001 en que, en base a un completo análisis de la prueba, se llega a la conclusión de que no hay intención defraudatoria en la falta de pago de un contrato de hospedaje.
} 
Barrientos - Recurso efectivo contra la sentencia...

[...] que se realice una interpretación amplia de las posibilidades de revisión en sede casacional y que el derecho reconocido en el Pacto se interprete no como el derecho a una segunda instancia con repetición íntegra del juicio, sino como el derecho a que un Tribunal superior controle la corrección del juicio realizado en primera instancia, revisando la correcta aplicación de las reglas que han permitido la declaración de culpabilidad y la imposición de la pena, en el caso concreto. Reglas entre las que se encuentran, desde luego, todas las que rigen el proceso penal y lo configuran como un proceso justo, con todas las garantías; las que inspiran el principio de presunción de inocencia, y las reglas de la lógica y la experiencia conforme a las cuales han de realizarse las inferencias que permiten considerar un hecho como probado.

La STC 70/2002 afronta probablemente la cuestión más difícil en materia casacional: la posibilidad de revisión de los hechos, por un tribunal distinto al de la instancia. Sobre este punto el Tribunal Constitucional señala que:

c) Conviene, no obstante, realizar alguna precisión adicional respecto de las posibilidades de revisión en sede casacional y, en concreto, de la posibilidad de examinar los hechos probados. Y ello para poder responder a la cuestión de si existe o no la posibilidad de una "revisión íntegra" del fallo condenatorio y la pena impuesta, entendiendo por tal la que permite, junto a la revisión de los aspectos formales o legales de la Sentencia (lo que, conforme al Dictamen del Comité, por sí solo no cumple con las garantías derivadas del Pacto), la revisión de los hechos probados en los que se fundamenta el fallo condenatorio.

La STC 116/2006, además de reiterar los planteamientos de la STC 70/2002, hace acopio de la jurisprudencia del Comité de Derechos Humanos que desde 2002 ha rechazado sistemáticamente las quejas presentadas contra España por el alcance de la revisión casacional.

\section{V.- Racionalidad del sistema de recursos penales en relación a la impugnación de la sentencia definitiva que no concede beneficios de la Ley $\mathrm{N}^{\circ}$ 18.216.}

Hasta el momento hemos efectuado un análisis que ha incluido las razones para establecer los recursos procesales, la pertenencia del derecho a recurrir al contenido esencial del debido proceso y la necesidad de la ampliación de la revisión judicial de las sentencias condenatorias. Todo esto, a mi juicio, contribuye a acumular una serie de buenas razones para postular la necesidad de la existencia 
de un recurso efectivo o eficaz que permita impugnar la sentencia condenatoria en aquella parte que niega el cumplimiento alternativo de la pena.

Lo que quiero evidenciar ahora es la falta de racionalidad de la distinción que está detrás de la impugnabilidad o no impugnabilidad de la sentencia que no concede los conocidos "beneficios de la Ley N $\mathrm{N}^{\circ}$ 18.216".

Según consta en el Primer Informe recaído sobre el proyecto de Ley Adecuatoria, la entrada en vigencia del nuevo Código Procesal Penal y de otros textos normativos tendría, por el carácter sistémico de todo ordenamiento jurídico y la necesidad de correspondencia y armonía interna, importantes repercusiones en el resto del ordenamiento jurídico del país. Ello obligaba a realizar, como lo sostuvo la Comisión de Justicia y Legislación de la Cámara de Diputados, las modificaciones o abrogaciones que dichos cuerpos legales producirían en el ordenamiento, especialmente en las leyes cuya aplicación depende del juicio penal o que contienen remisiones al Código que lo reglamenta. ${ }^{82}$

Es así, como se modificó el art. 25 de la Ley $\mathrm{N}^{\circ}$ 18.216. La intención original en relación a éste precepto era su derogación, esto es, eliminar el recurso de apelación tanto respecto de las decisiones denegatorias y revocatorias de beneficios. La respectiva Comisión del Senado advirtió que, si se aprobaba la derogación, no se podría apelar de la resolución que deniegue un beneficio ni de la que lo revoque. La Comisión señaló que le parecía que podría justificarse en el caso de la negativa, pero, tratándose de la revocación de un beneficio ya concedido y del cual puede haberse encontrado gozando largo tiempo una persona, es razonable permitir que tal medida pueda ser revisada por el tribunal superior. Se prefirió, por tanto, sustituir el artículo, y redactarlo tal cual lo conocemos hoy. ${ }^{83}$

No existe en la tramitación de la Ley Adecuatoria ninguna referencia más a esta modificación ni la expresión de razones que justifiquen la eliminación de la apelación respecto de la decisión denegatoria de beneficios. No hubo tampoco un análisis de proporcionalidad acerca de la entidad del sacrificio del derecho al recurso, de forma de establecer si la supresión de la apelación era realmente la medida más idónea para velar por la vigencia del principio de inmediación, si existía otra medida o alternativa menos restrictiva e igualmente eficaz, o si, en un juicio de estricta proporcionalidad, lo que se ganaba era en realidad más valioso que lo que se perdía. ${ }^{84}$

\footnotetext{
82 Primer Informe de la Comisión de Constitución, Legislación y Justicia de la Cámara de Diputados, 20 de octubre de 1998, Boletín N²217-07.

${ }^{83}$ Primer Informe de la Comisión de Constitución, Legislación, Justicia y Reglamento del Senado, 16 de octubre de 2001, Boletín N²217-07.

${ }^{84}$ En voto disidente de los ministros del Tribunal Constitucional chileno, don Hernán Vodanovic Schnake, don Mario Fernández Baeza y don Jorge Correa Sutil en sentencia dictada en causa Rol $N^{\circ}$ 986-2007, de 30 enero de 2008, sobre requerimiento de inaplicabilidad del art. 387 inciso $2^{\circ}$ del $\mathrm{CPP}$, se puede encontrar un excelente análisis de la razonabilidad de las leyes, especialmente sobre
} 
Barrientos - Recurso efectivo contra la sentencia...

La única explicación se refiere a la necesidad de armonizar el ordenamiento legal chileno con el nuevo sistema de enjuiciamiento penal. En el caso concreto del art. 25 la armonización que se buscaba era con el sistema recursivo del Código Procesal Penal.

Si, como sostiene Michele Taruffo, hay dos sentidos de racionalidad de la ley procesal: racionalidad como coherencia de la ley procesal y racionalidad como funcionalidad (o racionalidad instrumental), habrá que preguntarse si la adecuación del ordenamiento jurídico chileno al nuevo sistema procesal penal, en la materia que nos ocupa, cumplió o no con esas dos facetas de la racionalidad ${ }^{85}$.

La racionalidad como coherencia exige algunas propiedades que presentes permiten evaluar positivamente un sistema. Estas propiedades, entre otras, son: a) el orden, esto es, la secuencia en la cual vienen reguladas las actividades procesales y las relaciones entre normas generales y especiales; b) la unidad, es decir, la existencia de un contexto único con un núcleo de normas fundamentales y, en lo posible, con pocas normas especiales; c) la plenitud, v. gr. una ley procesal que regule todos los aspectos relevantes de los mecanismos procedimentales, dejando un margen mínimo a la fantasía de los intérpretes, y; d) la simplicidad que dice relación con la claridad de la regulación procedimental. ${ }^{86}$

Probablemente desde esta perspectiva se podría juzgar positivamente el resultado de la Ley Adecuatoria. Se trató de regular las relaciones entre normas generales y especiales; indudablemente el Código Procesal Penal es "La" ley procesal para el ejercicio del ius puniendi y para la defensa de los derechos de los intervinientes; se trata, en términos relativos, de un texto de fácil comprensión, redactado para que sea entendido por el ciudadano medio.

La racionalidad instrumental, axiológicamente más exigente, requiere que la regulación procedimental sirva adecuadamente a los fines de la administración de justicia. Dentro de estos fines, M. Taruffo menciona, la actuación de la ley penal en el caso particular, la formulación de decisiones justas y la efectiva tutela de los derechos de los sujetos interesados. Podemos decir que los fines enunciados pueden ser considerados los fines de la administración de justicia penal en Chile.

Es aquí donde, para juzgar su racionalidad, corresponde observar la instrumentalidad de las normas procedimentales que existen en nuestro ordenamiento en relación con la finalidad (o finalidades) del sistema procesal. ${ }^{87}$

\footnotetext{
la falta de justificación de la incorporación de un precepto legal durante la tramitación legislativa. Al respecto se puede consultar el considerando 16 del voto de minoría.

85 Taruffo, M., ob. citada, p. 311.

${ }^{86}$ Ibidem, p. 312.

${ }^{87}$ En el voto disidente mencionado en la nota 95, se discurre, también en el considerando 16, sobre la conveniencia de determinar, ante la endeblez intrínseca de un razonamiento que no se desarrolla
} 
Entonces, para establecer si el proceso penal chileno es racional debemos preguntar, si éste se desarrolla en un plazo razonable; si contempla normas probatorias idóneas que permitan una decisión fáctica acertada; si comprende instrumentos que promueven o garantizan la realización efectiva de los derechos, o; si contempla remedios para el control relativo a la justicia de las decisiones. ${ }^{88}$ Probablemente en la mayoría de esos ítems la respuesta sería satisfactoria. Mi duda dice relación con el último. ¿Contempla el sistema procesal chileno remedios para el control de las decisiones de los tribunales orales y de garantía respecto de las decisiones sobre beneficios de la Ley $\mathrm{N}^{\circ} 18.216$ ?

Si entendemos que la racionalidad de un sistema procesal penal está vinculada a las finalidades que inspiraron su creación y que deben inspirar su funcionamiento, debemos preguntarnos qué objetivos se tuvieron en mente al momento de la instauración del CPP. Sin duda uno de ellos, fue la verificación y punición de los delitos. Pero no es éste el único objetivo. Desde el artículo $1^{\circ}$ hasta el último artículo del CPP se desprende que también se concibió al proceso penal como el ámbito en que el imputado puede hacer valer la defensa de sus intereses. El punto, es saber cuál es el rol que cumplen esas finalidades. Podemos acordar que la primera finalidad es esencial, esto es, el proceso penal no sería lo que es sin ella. La segunda, es también esencial, pero probablemente en un sentido distinto, que podríamos llamar valorativo. Un proceso penal puramente determinado por la idea de la punición sería un proceso penal desprovisto de legitimidad. El segundo de los fines mencionados determina la existencia de un proceso penal verdaderamente legítimo. Y éste, para conservar su legitimidad y evitar que mute en mera legalidad, no puede asentarse, por ejemplo, en un sistema de garantías meramente formales, como tampoco puede justificar la cancelación de un derecho para satisfacer otro, si no existe la constatación y justificación racional que ambos no pueden coexistir en el sistema.

En relación con el párrafo anterior quiero formular dos observaciones. Por un lado, me parece que, con la reiterada jurisprudencia de nuestros tribunales superiores, no hay que decir mucho más respecto del carácter meramente formal de la posibilidad de impugnar la no concesión de beneficios. Este factor que influye en la falta de racionalidad entre la regulación procedimental y los fines de la administración de justicia, lo doy por explicado con lo expuesto en la primera parte

conceptualmente y tampoco se ha explicitado oficialmente, en la verificación de su razonabilidad, si la limitación al ejercicio del derecho que importa es proporcional a la finalidad de la norma. Así se dice que “... si se coloca de un lado el derecho de un imputado criminal a recurrir en contra de la sentencia que lo condena, se comprueba el carácter esencial de la norma que protege el derecho fundamental, garantizado por la Constitución y los tratados internacionales, de resguardar su libertad. La simple consideración de elementos económicos o de eficacia de la potestad sancionatoria no constituye una finalidad equivalente a la protección de derechos fundamentales. El medio escogido no es congruente con su supuesta finalidad y representa la exclusión de derechos subjetivos trascendentales;..." Similar razonamiento se puede encontrar en el considerando 18 del voto disidente.

${ }^{88}$ Ibídem.. 
Barrientos - Recurso efectivo contra la sentencia...

de este trabajo (I.b.), y; por otro, la ley procesal (y el artículo 25 de la Ley $\mathrm{N}^{\circ}$ 18.216 lo es) ${ }^{89}$ puede ser irracional desde un punto de vista funcional o instrumental, si no se expresan razonablemente y se justifican los factores que motivan una reglamentación diferente del derecho al recurso, contraria a los fines declarados por el sistema. Uno de estos, conviene no olvidarlo, es que el procedimiento y la investigación sean racionales y justos, y esto incluye la facultad de impugnar las sentencias que son dictadas por tribunales inferiores.

Veamos, entonces, usando el lenguaje de la Comisión del Senado, si "podría justificarse" la eliminación del recurso de apelación respecto de la resolución denegatoria de beneficios. Como lo sostuvimos, la principal razón justificante de la supresión de la apelación es el principio de inmediación. ¿Es esta justificación/explicación aplicable a la sentencia penal en cuanto no concede el cumplimiento alternativo de la pena? En nuestra opinión no se puede aplicar porque la decisión en esta materia, independientemente de la clase de procedimiento de que se trate, se adopta considerando antecedentes escritos. ${ }^{90}$ Podríamos, me parece, formular la misma afirmación, incluso, si un perito declarase en la audiencia de determinación de pena sobre las características personales del condenado pues al tratarse de una opinión técnica, reproducida íntegramente a través del audio respectivo, podría absolutamente ser revisada en sede de nulidad. Empleando el lenguaje de Gabriel Pérez Barberá y Hernán Bouvier, la decisión judicial que se basa en la opinión oral (o escrita) del perito constituye un enunciado inferencial. Según estos autores se puede distinguir entre enunciados inferenciales y enunciados de inmediación. Los primeros son aquellos que derivan de otros enunciados $\mathrm{y}$, por tanto, conforman argumentos $\mathrm{o}$ razonamientos. Como tales, pueden ser revisados por un tribunal que no esté en igualdad de condiciones epistémicas con el que los emitió, pues la tarea de revisión, en estos casos, se limita a un control de inferencias, que en tanto tal

\footnotetext{
89 Para una distinción entre ley procesal penal y ley penal, se puede consultar Beling, Ernst von, Derecho Procesal Penal, Traducción del alemán y notas por Miguel Fenech, Edit. Labor S.A, Barcelona, 1943. Ver Sección VI. Conclusiones. 1.-Naturaleza penal de los beneficios de la Ley $\mathrm{N}^{\circ}$ 18.216.

${ }^{90}$ Existe mucha confusión sobre el sentido de la expresión "antecedentes" empleada por el art. 343 del C.P.P. En sentencia de 2 de agosto de 2006 la Corte de Apelaciones de La Serena, en causa Rol No 194-2006, señaló, aludiendo al art. 343 inciso final del Código Procesal Penal, que: "El sustantivo antecedentes utilizado en esta disposición, por mucha amplitud que quiera dársele, no se compadece con la prueba pericial que quiso incorporar la defensa para rebatir las conclusiones del informe presentencial que presentó el Ministerio Público,...”. En esta causa la defensa dedujo recurso de nulidad fundado en la causal del art. 374 letra c), toda vez que se impidió al defensor incorporar, en la audiencia del art. 343 del C.P.P., como antecedentes los informes periciales psicológicos y sociales realizados al imputado. Por el contrario, en sentencia de 26 de enero de 2006, en causa RIT 95-2005, RUC 0510009415, del Tribunal Oral en lo Penal de Santiago, durante el debate de determinación de pena en que se discutía la concurrencia de la atenuante de imputabilidad disminuida, se recibió prueba pericial no contemplada en el auto de apertura. Esta última sentencia aparece citada en el trabajo de Briceño Domínguez, Sebastián, "Observaciones al art. 343 inc. $4^{\circ}$ CPP”, La Semana Jurídica $N^{\circ} 303$, edición del 28 de agosto al 3 de septiembre de 2006.
} 
puede ser llevado a cabo por cualquiera. Los segundos, en cambio, son los que derivan de una relación sujeto-mundo. Un enunciado de inmediación no se apoya en otros enunciados, sino en percepciones sensoriales respecto del entorno empírico. Tales percepciones forman parte del lenguaje privado del hablante y, en consecuencia, son intersubjetivamente comunicables, pero no controlables. ${ }^{91}$

¿Podría un tribunal superior estar en las mismas condiciones, par conditio, que el o los jueces de mérito para acceder, analizar y resolver sobre una petición de la defensa que se funda en extractos de filiación, informes presentenciales o informes sociales, absolutamente reproducibles en otro grado jurisdiccional? La respuesta es positiva. ${ }^{92}$ Esta respuesta se refuerza especialmente después de la entrada en vigencia de la Ley $\mathrm{N}^{\circ} 20.074$ del 2005, que reemplazó el art. 343 original del Código Procesal Penal. ${ }^{93}$ Desde este momento es aún más claro que la existencia de un recurso respecto de las medidas alternativas de la Ley $\mathrm{N}^{\circ} 18.216$ no afectaría al principio de inmediación en la decisión del asunto central del juicio oral, pues la decisión sobre el otorgamiento de medidas alternativas se hace sobre la base de antecedentes escritos que son leídos por el tribunal oral, como ocurrió en el caso que originó nuestro fracasado requerimiento y que, por lo mismo, pueden ser también leídos por el tribunal de alzada. Lo anterior hace que los jueces del tribunal superior se encuentren, en este aspecto, en una par conditio con los jueces de la instancia.

Precisamente en el caso que dio origen al requerimiento, no se le concedió al condenado ninguno de los beneficios de la Ley $\mathrm{N}^{\circ}$ 18.216, luego que se incorporaran materialmente, en la audiencia del art. 343 del Código Procesal Penal, conocida como audiencia de determinación de pena, antecedentes escritos para decidir si era o no merecedor del cumplimiento alternativo, concretamente de la libertad vigilada.

Por ello, sostenemos (y sostuvimos ante el Tribunal Constitucional) que si la razón para eliminar el recurso de apelación fue privilegiar la inmediación, se puede afirmar categóricamente que no existía (antes de la Ley $\mathrm{N}^{\circ}$ 20.074) ni existe ahora justificación racional, en los términos del art. $19 \mathrm{~N}^{\circ} 3$ inciso 5 de la CPR.

\footnotetext{
${ }^{91}$ Ver: Pérez Barberá, Gabriel y Bouvier, Hernán, Casación, lógica y valoración de la prueba, en Nueva Doctrina Penal 2004/B.

${ }^{92}$ En mi opinión no se puede plantear como objeción el que los jueces del tribunal que conozca el recurso no vean al acusado. Me parece que no tiene importancia la sola apreciación visual del imputado. No se puede fundar racionalmente la decisión de no otorgar beneficios en lo que los jueces puedan pensar del imputado con solo verlo. De lo contrario se exagerarían los efectos y ventajas de la inmediación.

${ }^{93}$ El art. 343 del Código Procesal Penal señala, en lo pertinente, que para la determinación de la pena y la modalidad de cumplimiento “[...], el tribunal recibirá los antecedentes que hagan valer los intervinientes para fundamentar sus peticiones, dejando su resolución para la audiencia de lectura de sentencia."
} 
Barrientos - Recurso efectivo contra la sentencia...

Una decisión legislativa fundada solamente en "un podría justificarse" y que no encuentra sustento en la principal razón hecha valer, incorpora en un proceso penal con visos de legitimidad, unas condiciones que, al no permitir el uso efectivo de los mecanismos de defensa, entre ellos, los recursos procesales, transforman a ese proceso en un proceso ilegítimo, pues existe un quiebre de su racionalidad instrumental.

Existen, en mi opinión, dos discriminaciones legislativas que manifiestan la falta de racionalidad del sistema de recursos, en lo referente a los beneficios de la Ley $\mathrm{N}^{\circ}$ 18.216. La primera concierne a la distinción entre decisión denegatoria y revocatoria de beneficios. La segunda, relativa a la distinción entre procedimientos que permiten o no la impugnación, fundado aparentemente en la garantía de la inmediación.

En las primeras páginas de este trabajo sostuvimos que una resolución que causa agravio en cuanto afecta un bien jurídico relevante debiera admitir la posibilidad de reprobación por parte del justiciable. A mi juicio una resolución que niega una modalidad de cumplimiento alternativo (cumplimiento en libertad de una pena), evidentemente causa agravio, lo que la hace absolutamente recurrible. Pretender discriminar entre una resolución que revoca un beneficio alternativo de una resolución que niega el acceso a él, carece de justificación racional suficiente. En el caso de la resolución denegatoria de beneficios de la Ley $\mathrm{N}^{\circ} 18.216$, al igual que en el de la revocatoria, se dan los supuestos básicos que justifican la existencia de los medios de impugnación ante el superior jerárquico: causación de agravio, eventualidad de error en la labor judicial y afectación de un bien jurídico relevante -libertad personal-. ¿Donde esta la diferencia que "podría justificar" un tratamiento legislativo distinto? Aplicando el $\mathrm{ABC}$ de las técnicas de interpretación jurídica, podríamos decir que donde hay la misma razón debe existir la misma disposición, siempre que no concurra ningún otro aspecto que lo impida o lo haga incompatible con otras garantías constitucionales.

La falta de racionalidad de la regulación procedimental se evidencia en el funcionamiento del sistema recursivo chileno. Recordemos que el recurso de nulidad procede sólo respecto de sentencias en juicios orales, ordinarios o simplificados y procedimientos simplificados con aceptación de responsabilidad, y que la apelación procede respecto de los procedimientos abreviados. La justificación de esta diferencia se muestra como evidente. En el procedimiento abreviado no hay inmediación, esto es, la resolución del juez se basa en los antecedentes de la carpeta de investigación, a los que los jueces del tribunal de alzada también pueden acceder. Esta justificación parece racional y razonable. Pero si se escudriña en la normativa y en su aplicación, nos percatamos que lo que está prohibido respecto de delitos graves, o respecto de delitos cuya tramitación concluye en un juicio oral, no está prohibido en el procedimiento abreviado. En este procedimiento se puede apelar incluso de los beneficios, y los tribunales así lo 
han admitido y acogido. ${ }^{94}$ En cambio, en causas que recaen sobre delitos con pena de crimen, en que no es aplicable el procedimiento abreviado o no se logra una negociación que lo permita, el acusado no tiene esa posibilidad. El juicio oral, concebido como la mayor de las garantías, donde la pretensión punitiva suele ser más intensa y, que por ello, debiera estar compensado con más y mejores derechos, se transforma en una pequeña trampa. Se accede a la mayor de las garantías, pero bajo el precio de que se pierde una de ellas y, lo peor, nadie proporciona una buena razón. Esta afirmación, que puede ser estimada una exageración, tiene un efecto demostrativo de la irracionalidad del sistema recursivo, pues quien decide enfrentar un juicio oral después de no haber aceptado la tramitación de un procedimiento abreviado deberá considerar que, en caso de condena a una pena que no exceda de presidio menor en su grado máximo, no podrá recurrir por el no otorgamiento de beneficios.

Los ejemplos demuestran mejor que una breve explicación la dimensión de este punto crítico. En la causa que dio origen al requerimiento, el imputado formalizado y acusado por varios delitos de estafa que perjudicaron a un número importante de personas, pero que no obstante bien pudo acceder a un procedimiento abreviado, después de la sentencia definitiva tenía clausurada la vía impugnativa, para cuestionar el único aspecto de la sentencia con el que se mostraba disconforme: la no concesión de beneficios. En cambio, en otra causa tramitada ante el Séptimo Juzgado de Garantía de Santiago un imputado contra quien se había formulado acusación por delitos que afectaron patrimonialmente, de manera considerable, a muchas personas, ante la denegatoria de beneficios, en virtud de sentencia dictada en un procedimiento abreviado, pudo impugnar la sentencia y revertir su situación. ${ }^{95}$

Se podrá insistir en que la diferencia es que en uno rigió la inmediación, mientras que en el otro se falló con el mérito de la carpeta fiscal. Y agregarse como argumento, en el primer caso, la colegialidad del tribunal sentenciador versus el carácter unipersonal del juez de garantía. Argumento, éste último, tan débil para restar las posibilidades impugnativas de los condenados que no merece mayor dedicación. ${ }^{96}$

En consecuencia, la pregunta que persiste es si esa diferencia (la inmediación) realmente existe. Creo que la respuesta es negativa. La diferencia, en

\footnotetext{
94 Corte Suprema, 9 de agosto de 2005, Rol N 3478-05; Cortes de Apelaciones: Santiago, 24 de enero de 2008, Rol N 53-08; San Miguel, 28 de abril de 2006, Rol N 377-06; Valdivia, 28 de marzo de 2007, Rol N 71-07; Antofagasta, 13 de febrero de 2007, N²4/2007.

${ }^{5}$ Se trata de la sentencia dictada por la Sala Octava de Corte de Apelaciones de Santiago el 24 de enero de 2008, en causa Rol 53-2208 (RUC 0600289809-6, RIT 7503-2006 del $7^{\circ}$ Tribunal de Garantía de Santiago).

${ }^{96}$ La debilidad de este argumento radica en que la colegialidad del tribunal no es un seguro frente a la posibilidad de error de los tribunales plurales. La supuesta mayor capacidad epistémica de un tribunal compuesto por tres jueces no puede constituirse en un argumento válido y definitivo para cerrar el acceso a los medios de impugnación.
} 
Barrientos - Recurso efectivo contra la sentencia...

este aspecto, no existe y no puede justificar la privación del recurso en un caso y la mantención en el otro. El Tribunal de Juicio Oral y el Juez de Garantía estuvieron, en los ejemplos recién referidos, en la misma condición, pues la decisión acerca de la concesión o no de algún beneficio se funda en antecedentes escritos (llámese extracto de filiación, informes sociales, informe presentencial). Si esto es así, la supresión del recurso de apelación, como la declaración de improcedencia del recurso de nulidad, para cuestionar solamente la decisión de un tribunal oral referida al no otorgamiento de beneficios, constituye un tratamiento discriminatorio, que al no tener una justificación racional resulta abiertamente inconstitucional, de acuerdo a las cláusulas del art. $19 \mathrm{~N}^{\circ} 2$ y 3 de la CPR. Tampoco tiene justificación racional la autolimitación que se observa, en sede de nulidad, en los tribunales superiores chilenos, pues si lo relativo a la discusión de los beneficios de la Ley $\mathrm{N}^{\circ} 18.216$ no está afectado por la inmediación, se puede, siguiendo la tesis del agotamiento de la capacidad de revisión (revisión integral), examinar su corrección jurídica. ${ }^{97}$

Otra demostración de la carencia de racionalidad del sistema recursivo está en la imposibilidad de recurrir cuando la decisión denegatoria se emite en un procedimiento simplificado con aceptación de responsabilidad. Esta clase de procedimiento se parece más a un abreviado que a un juicio oral, y no obstante alguien que es condenado a 61, 100 o 540 días de privación de libertad no puede recurrir si el tribunal le niega el acceso al cumplimiento alternativo. Nadie podrá levantar el argumento de la inmediación porque aquí no concurre. El juez de garantía falla con los antecedentes aportados por el fiscal y con la aceptación del imputado. Si existe discusión sobre los beneficios el juez generalmente resuelve en base a los antecedentes de la carpeta y de los documentos que se presentan al tribunal. ¿Alguien podría decir que la Corte de Apelaciones no estaría par conditio con el juez para revisar su decisión en este rubro?

La irracionalidad radica, en este caso, que delitos que en abstracto tienen una reprochabilidad menor no dan lugar al ejercicio de una garantía tan importante como la impugnación procesal, mientras que otros que suscitan un mayor reproche sí habilitan para recurrir, fundado en una diferencia procedimental - la inmediación- que en el caso no existe. ${ }^{98}$

\footnotetext{
97 Podríamos formular esta misma afirmación, incluso, si un perito declarase en la audiencia del art. 343, pues al tratarse de una opinión técnica, reproducida íntegramente a través del audio respectivo, podría absolutamente ser revisada en sede de nulidad.

98 Debemos hacer constar que, a diferencia de lo que sostenemos, el Comité de Derechos Humanos en el caso Gómez. Vásquez c. España expresó que: "11.2 Con respecto a la supuesta violación del artículo 26 del Pacto porque el sistema español prevé distintos tipos de recurso según la gravedad del delito, el Comité considera que un tratamiento diferenciado respecto de diferentes delitos no constituye necesariamente una discriminación. El Comité considera que el autor no ha sustanciado una violación el artículo 26 del Pacto en este respecto".
} 
Por otra parte, conociendo el criterio jurisprudencial empleado, sabemos que por la vía del recurso de nulidad es imposible, o a lo menos riesgoso 99 , impugnar la sentencia definitiva en cuanto no concede el cumplimiento alternativo. Existe, entonces, no sólo una clausura legal para recurrir, sino que también una clausura judicial para hacerlo. Es el sistema procesal penal el que, en su normatividad legal y en su operatividad judicial, obstruye al condenado el recurso para cuestionar la no concesión de beneficios. Frente a una clausura tan absoluta, sería esperable también una justificación racional. Esa justificación no existe. Por el contrario, hay, además de una restricción indebida del derecho al recurso no congruente con la idea de la revisión integral, una inconsistencia lógica en el razonamiento que impide el acceso al recurso de nulidad.

Dijimos ya cuáles eran las razones de la Corte Suprema y de las Cortes de Apelaciones para declarar inadmisibles los recursos de nulidad. El argumento principal, además de la naturaleza restringida del recurso de nulidad, es que lo concerniente al otorgamiento o no de los beneficios contemplados en la Ley $\mathrm{N}^{\circ}$ 18.216 no forma parte de la sentencia definitiva del proceso penal. Esos fundamentos de inadmisibilidad demuestran que no hay intención de encontrar una vía para canalizar las pretensiones recursivas. Por el contrario, evidencian la lógica del minimo esfuerzo revisor.

Donde se hace patente la falta de justificación racional de la jurisprudencia de la Corte Suprema, es en la sentencia de 9 de agosto de 2005 (Rol No 3478-05), que resolvió un recurso de queja en la causa contra Jorge Lavanderos. En esta causa, la Corte Suprema dijo para justificar el rechazo del recurso:

Que, sin perjuicio que lo anterior bastaría para desechar el recurso, en lo que a su primer capítulo se refiere, cabe dejar sentado que tratándose en la especie de un procedimiento abreviado, el otorgamiento de los beneficios alternativos de cumplimiento de pena - por mandato del artículo 413 letra e) del

\footnotetext{
99 Una demostración de lo riesgoso que puede ser, nos la proporciona el siguiente ejemplo. En causa RIT N ${ }^{\circ}$ 19-2006, RUC 0500234830-8 del Sexto Tribunal de Juicio Oral en lo Penal de Santiago, con fecha 24 de marzo de 2006 se condenó a I.A.T.M. a la pena de 4 años de presidio menor en su grado máximo como autor de homicidio simple y a la pena de 60 días de prisión en su grado máximo por lesiones menos graves, sin beneficios de la Ley $\mathrm{N}^{\circ}$ 18.216. La defensa recurrió de nulidad fundado en los motivos absolutos del art. 374 letra e y c del CPP. Se solicitó la nulidad de la sentencia y del juicio oral pues el tribunal no había motivado la no concesión de la libertad vigilada. La Corte de Apelaciones de San Miguel, acogiendo lo señalado por la defensa en cuanto a la falta de motivación respecto del beneficio, anuló la sentencia y el juicio oral por sentencia de fecha 5 de mayo de 2006, Rol Ingreso $\mathrm{N}^{\circ}$ 338-2006. No hubo actividad recursiva del Ministerio Público. En el segundo juicio llevado a cabo en el mismo tribunal, por jueces no inhabilitados, por sentencia definitiva de fecha 19 de junio de 2006 se condenó al acusado a la pena de 5 años y un día de presidio mayor en su grado mínimo por el delito de homicidio simple y a multa de una UTM, como autor del delito de lesiones leves, lo que hizo absolutamente improcedente la concesión de beneficios.
} 
Barrientos - Recurso efectivo contra la sentencia...

Código Procesal Penal - forma parte de la sentencia definitiva y por ende es susceptible del recurso de apelación, con arreglo a lo dispuesto en el artículo 414 del Código Procesal Penal.

Lo que la Corte afirma es absolutamente cierto. El art. 413 dice lo que la Corte refiere. Pero el art. 348 del CPP, sobre el contenido de la sentencia condenatoria del juicio oral, expresa en su inciso primero lo mismo que el art. 413. ¿Dónde está la diferencia? En un caso, según la Corte, la decisión sobre los beneficios integra la sentencia, mientras que en el otro, mediando solamente una distinta ubicación del precepto pero sin variación de contenido, esa misma decisión no forma parte de la sentencia definitiva. Por lo menos habría que exigir una explicación.

Aquí conviene recordar lo que señalaba el juez Fayt de la Corte Suprema argentina, en el sentido que construir el sistema de recurso en la etapa de ejecución sobre la base de la distinta "naturaleza jurídica" de las resoluciones carece de toda fundamentación. La distinción que formula la Corte Suprema chilena es meramente dogmática y, además, carece absolutamente de sustento legal, como se expresó en el párrafo anterior. Si la Corte señala que no es sentencia definitiva aquello que está resuelto en la sentencia definitiva lo esperable es que asumiese, en honor a la seguridad jurídica, la carga de explicar qué tipo de resolución es. Si cree que se trata de una sección meramente administrativa de la sentencia debería decir por qué sostiene eso. Tras los asertos de la Corte, lo que hay es la aplicación de una fórmula economicista, producto del "mero voluntarismo judicial".

Probablemente la irracionalidad (parcial) del sistema recursivo genera soluciones que comparten esa característica. La inconsistencia lógica del sistema legal abre, como diría Taruffo, camino a la "fantasía de los intérpretes".

Si tengo razón en lo que he dicho en las líneas precedentes, el legislador al creer que "podría justificarse" esta decisión se equivocó y ya es hora de remediar ese error. Cierto es que el actual artículo 25 de la Ley 18.216, es una norma existente y obligatoria, pero eso no la hace buena e incuestionable. Precisamente porque con su actual redacción tiene la virtualidad de impedir la realización de, por lo menos, dos de los tres fines de la administración de justicia que mencionamos más arriba, a saber, la formulación de decisiones justas y la efectiva tutela de los derechos de los sujetos interesados, resulta un norma que carece de racionalidad instrumental. Racionalidad que hay que apreciar, en todo caso, teniendo en mente no sólo el restringido marco normativo nacional, sino especialmente el internacional y comparado. Frente a este escenario, los tribunales debieran hacer primar las normas internacionales que claramente tienen una jerarquía normativa superior a la ley. ${ }^{100}$

100 La Sala Constitucional de la Corte Suprema de Costa Rica en Sentencia 282-90, declaró que, sin perjuicio de la facultad de ejercer una acción de inconstitucionalidad contra disposiciones legales internas que se opongan a un tratado internacional, "cuando las normas de un tratado resulten 
REJ - Revista de Estudios de la Justicia - No 11 - Año 2009

\section{VI.- Cinco razones para sostener la impugnabilidad de la sentencia denegatoria de beneficios.}

Creo que ha quedado suficientemente claro que no existe recurso efectivo, salvo en el procedimiento abreviado, para impugnar la sentencia definitiva condenatoria que no concede beneficios de la Ley $\mathrm{N}^{\circ}$ 18.216. La regla general es que ni el recurso de apelación ni el recurso de nulidad constituyen medios efectivos para recurrir contra la sentencia, dictada en juicio oral, simplificado u ordinario y en un procedimiento simplificado con admisión de responsabilidad, en lo concerniente a los beneficios de la Ley $\mathrm{N}^{\circ} 18.216$, ya que, el primero no está contemplado por el Código Procesal Penal, mientras que el segundo no permite hoy proveer una respuesta de fondo respecto de la pretensión impugnativa. ${ }^{101}$

Es evidente que si una ley niega el acceso a un determinado recurso (apelación) en una determinada materia, y una interpretación judicial niega la admisibilidad de un recurso de otro carácter (nulidad) en la misma materia, estamos frente a un sistema procesal que desconoce el derecho a recurrir. Esta respuesta sistémica es, en mi opinión, contraria a los preceptos constitucionales y a las normas internacionales que, por mandato del art. 5 de la Constitución Política del Estado, obligan a los órganos del Estado, si se considera que respecto de la resolución denegatoria de beneficios de la Ley $\mathrm{N}^{\circ} 18.216$ se dan los supuestos básicos que justifican la existencia de los medios de impugnación ante el superior jerárquico: causación de agravio, eventualidad de error en la labor judicial y afectación de un bien jurídico relevante -libertad personal-. La respuesta estatal no

ejecutivas y ejecutables por si mismas, sin necesidad de otras normas que las desarrollen en derecho interno, las legales que las contradigan deben tenerse simplemente por derogadas, en virtud precisamente del rango superior del tratado. De esta manera la antinomia... se resuelve en primer lugar en lo posible por la derogación automática de la primera en cuanto se oponga a lo segundo, sin perjuicio de que también pueda serlo mediante la declaración de inconstitucionalidad de la ley". Fuente: Informe $N^{\circ}$ 24/92, casos 9328, 9329, 9742,9884, 10131, 10.193, 10.230, 10.429, 10.469 (Costa Rica), Derecho de Revisión de Fallo Penal, 2 de octubre de 1992.

101 A continuación dos casos que demuestran, por un lado, que la defensa no ha desistido en su búsqueda de mecanismos para recurrir contra las sentencias que no conceden beneficios de la Ley $\mathrm{N}^{\circ} 18.216 \mathrm{y}$, por otro, que los tribunales de justicia no han respondido adecuadamente a las peticiones fundadas en el derecho constitucional al recurso. En la causa Rol No 202-2007 de la Corte de Apelaciones de Puerto Montt se declaró inadmisible un recurso de apelación intentado por la defensa, que asilada en la misma doctrina de la Corte Suprema, impugnó una sentencia definitiva dictada en procedimiento simplificado con admisión de responsabilidad por el Tribunal de Garantía de Castro, insinuándose que era procedente el recurso de nulidad. Asimismo, se intentó ante la Corte de Apelaciones de San Miguel una acción constitucional de amparo en contra de una sentencia definitiva del Tribunal Oral en lo Penal de Puente Alto que denegó la libertad vigilada a una ciudadana peruana que fue condenada a 4 años de presidio menor en su grado máximo y respecto de la cual existía un informe presentencial favorable. Por sentencia de 30 de enero de 2008 en causa Rol N 321-2007, la Corte de San Miguel rechazó el amparo señalando que la concesión de beneficios era una facultad privativa de los sentenciadores, que el informe presentencial no era vinculante y que no se proporcionaron en la audiencia antecedentes satisfactorios de acuerdo al art. 15 letra c) de la Ley $\mathrm{N}^{\circ} 18.216$. 
Barrientos - Recurso efectivo contra la sentencia...

sólo es insatisfactoria, sino que sobre todo es inconsistente con los fines de la administración de justicia.

A continuación, fundado principalmente, aunque no de manera exclusiva, en el análisis previo sobre la normativa internacional aplicable, la noción de revisión integral y las críticas planteadas respecto de la racionalidad del sistema recursivo, formulo cinco razones (jbuenas espero!) para abogar por la impugnabilidad de la sentencia denegatoria de beneficios de la Ley $\mathrm{N}^{\circ}$ 18.216.

\section{1.- Naturaleza penal de los beneficios de la Ley $N^{\circ} 18.216$.}

En primer lugar, no hay buenos argumentos para insistir en el aserto que la decisión sobre las medidas alternativas al cumplimiento de la pena no es un requisito propio del contenido de la sentencia definitiva condenatoria. El art. 348 del CPP permite sostener, sin vacilación, que lo que está en la sentencia definitiva por mandato legal no puede sino compartir dicho carácter. Si bien es cierto que la cuestión central del juicio penal está constituida por la determinación sobre la inocencia o culpabilidad del imputado, eso no obsta a considerar que cuando ello ha ocurrido, el "asunto objeto del proceso" pasa a ser la pena aplicable y la modalidad que ésta puede adoptar. La determinación de la naturaleza penal de las normas sobre beneficios de la Ley $\mathrm{N}^{\circ} 18.216$, contribuye a reforzar nuestra posición y, de paso, desvirtúa la infundada distinción que formulan los tribunales entre cuestiones que son parte de la sentencia definitiva penal y otras que no. ${ }^{102}$

La mayoría de los manuales y tratados de Derecho Penal se ocupan, al tratar la Teoría de la Pena, de las medidas alternativas al cumplimiento de las penas privativas de libertad, lo que permite suponer que existe consenso en estimarlas una materia estrictamente penal. ${ }^{103}$ Se distingue así entre medidas relativas a la suspensión de la ejecución de la pena privativa de libertad y las penas alternativas a la prisión propiamente, incluyéndose, en las primeras, a la remisión condicional de la pena y a la libertad vigilada y, en las segundas, a la reclusión nocturna. ${ }^{104}$ Las primeras constituyen una suspensión de la ejecución de la pena sujeta a determinadas condiciones, lo que permite al profesor Raúl Zaffaroni sostener que trata de condenas sometidas a condición resolutoria ${ }^{105}$, por lo que podríamos decir

\footnotetext{
${ }^{102}$ Le agradezco a Enrique Letelier haber llamado mi atención sobre este punto, el que con toda seguridad merece un mayor desarrollo del que soy capaz en este momento.

103 Por ejemplo, Bustos Ramírez, Juan, Obras Completas, Tomo I Derecho penal Parte General, Ara Editores, Perú, 2004, pp. 735-741; Politoff L., Sergio, Matus A. Jean Pierre y Ramírez G., María Cecilia, Lecciones de Derecho Penal Chileno, Parte General, Editorial Jurídica de Chile, $1^{\circ}$ edición, Santiago de Chile, 2004, pp-539-551; Garrido Montt, Mario, Derecho Penal, Parte General Tomo I, Editorial Jurídica de Chile, Santiago de Chile, 2001, pp.339-352; Zaffaroni, Eugenio Raúl, Derecho Penal. Parte General, Ediar, Buenos Aires, 2002, pp. 949-970.

104 Politoff L., Sergio, Matus A. Jean Pierre y Ramírez G., María Cecilia, Lecciones de Derecho Penal Chileno, ob. citada, p. 539.

105 Zaffaroni, Eugenio Raúl, Derecho Penal, ob. citada, p. 965. Horvitz L., María Inés, en "Las Medidas Alternativas a la Prisión (Algunas reflexiones en torno a las medidas previstas en la Ley 18.216)",
} 
REJ - Revista de Estudios de la Justicia - No 11 - Año 2009

que se trata de una pena en potencia. Mientras que la segunda, en cuanto es una forma alternativa de cumplimiento de la pena consistente en una privación parcial de la libertad, sigue compartiendo el carácter de sanción, toda vez que supone, aunque con menor intensidad, un sacrificio de determinados intereses y derechos legítimos.

En Chile, salvo un breve trabajo de María Inés Horvitz Lennon, no conocemos un estudio que se refiera expresamente a la naturaleza jurídica de los beneficios. Horvitz, sin tratar específicamente esta cuestión, señala que en nuestro país las medidas alternativas no se contemplan como reacciones autónomas a determinados supuestos delictivos sino solamente como posibilidad alternativa a determinadas penas privativas o restrictivas de libertad. Sin embargo, en su opinión, sería deseable desde una perspectiva político-criminal que las medidas alternativas fuesen autónomas dentro de un sistema sancionatorio diferenciado, con lo que se inclina, me parece, por la naturaleza penal de los beneficios. Más adelante, Horvitz expresamente asume esta posición al aseverar que las medidas alternativas conllevan restricciones a los derechos individuales y, en este sentido, se aproximan a las penas en sentido material. ${ }^{106}$

Para fundar la naturaleza penal de las medidas alternativas, conviene recordar a Ernst Beling, según el cual la ley penal responde a las preguntas de si debe imponerse pena, cuál sea ésta y con qué requisitos, mientras que la ley procesal penal responde a si hay lugar a proceder, cómo debe ser el proceso y cuáles sus requisitos. La naturaleza penal o procesal de una norma, debe ser decidida considerando si, por un lado, las circunstancias que condicionan la consecuencia jurídica están situadas dentro del ámbito del Derecho donde se estatuye acerca de la pertinencia de la inflicción del mal de la pena o si tales circunstancias son de tal suerte que no se adaptan al círculo de las ideas penales y sí en cambio al de las que determinan el "si" y el "cómo" de la actividad procesal. ${ }^{107}$ Claramente las normas sobre medidas alternativas al cumplimiento de las penas están incluidas en la disciplina jurídica en que se estatuye acerca de "la pertinencia de la inflicción del mal de la pena”.

Cuadernos de Análisis Jurídico, $\mathrm{N}^{\circ} 21$, sostiene que, en los sistemas de suspensión de pena, hay una "renuncia condicionada al castigo".

106 Horvitz Lennon, María Inés, "Las Medidas Alternativas a la Prisión (Algunas reflexiones en torno a las medidas previstas en la Ley 18.216)", Cuadernos de Análisis Jurídico, Universidad Diego Portales, $\mathrm{N}^{\circ} 21$, mayo de 1992, pp. 140, 151.

107 Beling, Ernst von. Derecho Procesal Penal, Traducción del alemán y notas por Miguel Fenech, Edit. Labor S.A, Barcelona, 1943. Para la distinción, según Beling, no influye ni lo más mínimo el lugar donde el precepto legal se encuentre (en el Código penal o en el procesal) ni el tenor de la Ley (lo mismo que ésta hable de la "pena" que de "persecución del delito"). 
Barrientos - Recurso efectivo contra la sentencia...

\section{2.- La inmediación no es un límite a la revisión de la decisión denegatoria de medidas alternativas.}

En segundo lugar, la inmediación puesta en su correcta dimensión no puede servir como impedimento real para la revisión de la sentencia condenatoria en cuanto deniega el cumplimiento alternativo de la pena. Por un lado, si como se ha dicho, lo relativo a la concesión de beneficios de la Ley $\mathrm{N}^{\circ} 18.216$ es una materia que no surge única y directamente de la inmediación, no existe justificación racional - en los términos del art. 19. $\mathrm{N}^{\circ} 3$ inciso 5 de la Constitución Política-, para privar a la parte agraviada del derecho al recurso y, por otro, la misma afirmación de que "las cuestiones relativas a beneficios alternativos son un aspecto adjetivo del juicio" y, por ello, no afectada por la garantía de la inmediación, insostenible desde el punto de vista normativo, proporciona, al contrario de lo que creen sus promotores, un buen argumento para abogar por el restablecimiento del recurso de apelación o para propiciar un examen más amplio, en sede de nulidad, de la sentencia condenatoria en el aspecto que nos ocupa.

Nuestro objetivo, en todo caso, es a partir de la constatación de la inefectividad del sistema de recursos en lo concerniente a medidas alternativas al cumplimiento de penas privativas o restrictivas de libertad y de que la concesión de beneficios es una materia que no surge única y directamente de la inmediación, proponer, antes que la reinstauración del recurso de apelación, una adecuación del recurso de nulidad a la tesis del máximo esfuerzo revisor en la materia indicada. ${ }^{108}$ Lo anterior supone, como lo sostiene la Corte Suprema argentina, no magnificar el efecto de la inmediación y distinguir, en cada caso, los aspectos revisables de la sentencia.

\section{3.- La decisión sobre la concesión o denegatoria requiere fundamentación y es susceptible de revisión.}

La ampliación del recurso de nulidad a este extremo de la decisión judicial puede ser objetada arguyendo el supuesto carácter facultativo de las decisiones sobre las medidas alternativas de cumplimiento de la pena de la Ley $\mathrm{N}^{\circ} 18.216$. Se sostiene, generalmente, que la decisión sobre medidas alternativas es una facultad privativa del tribunal de fondo, que escapa al control del recurso de nulidad. Ésta constituye una segunda vía por la que la Corte Suprema renuncia a pronunciarse sobre los recursos deducidos para cuestionar el no otorgamiento de medidas de la Ley $\mathrm{N}^{\circ}$ 18.216. Se pueden plantear tres objeciones a este argumento. Primero, el cumplimiento de los requisitos formales y materiales exigidos por la ley hace surgir el derecho a la condicionalidad pues, de lo contrario, implicaría confundir la función valoradora del juez con una potestad arbitraria. Si bien se alude a beneficios, no se trata de decisiones graciosas o discrecionales, ya que reunidos los requisitos formales y materiales el condenado puede pedirlos y el tribunal debe concederlos. Segundo, la supuesta discrecionalidad de la decisión como límite a la

\footnotetext{
108 También en esto mi gratitud a Enrique Letelier.
} 
capacidad revisora se opone a la integralidad de la revisión. Tercero, incluso si se aceptase el carácter facultativo de este tipo de decisiones, ello no implica que se trate de una atribución arbitraria que no deba estar sometida a revisión.

No debe olvidarse que el art. 24 de la ley $\mathrm{N}^{\circ} 18.216$ exige que tanto la sentencia que concede como la que niega alguno de los beneficios expresen los fundamentos en que se apoya y los antecedentes que han dado base a su convicción. Esta obligación de fundamentar la decisión en este punto, en cuanto deber especifico de los jueces, conduce necesariamente a la posibilidad de revisión. ${ }^{109}$

La naturaleza penal de los beneficios de la Ley $\mathrm{N}^{\circ} 18.216$ y el carácter de derechos que se les atribuye, los sitúa en el plano estrictamente jurisdiccional y no administrativo o político. La expresión "podrá", como lo sostiene Zaffaroni, al tratar de la libertad condicional, no debe interpretarse como una facultad de decidir arbitriamente, incluso negando el acceso a la medida alternativa aún en el caso que el condenado reúna los requisitos legales sino, por el contrario, como una facultad del condenado a ejercer su derecho. ${ }^{10}$

4.- El sistema recursivo en relación con impugnación de la decisión denegatoria de beneficios de la Ley $N^{\circ} 18.216$ carece de racionalidad.

Desde un análisis racional del sistema de recursos del CPP, se puede afirmar que existe un sacrificio inútil del derecho al recurso en relación con los beneficios de la Ley $\mathrm{N}^{\circ} 18.216$, pues al resolverse la concesión de estos sobre antecedentes escritos, la eliminación del derecho a recurrir no supone una mayor efectividad de la garantía de la inmediación y, a la inversa, como se ha dicho, el establecimiento de recursos respecto de los beneficios señalados no perjudica o afecta la vigencia de la inmediación. La inutilidad del sacrificio, queda demostrada, pues antes de la clausura legislativa lo que correspondía, como medida menos restrictiva e igualmente eficaz, era efectuar, o intentar por lo menos, una interpretación armónica de la Constitución Política, de los tratados internacionales y de las leyes procesales que rigen la materia sobre que versa este ensayo, que compatibilice o concilie el derecho al juicio oral (garantía de la inmediación) y el derecho a recurrir del fallo, de forma tal que ninguno de esos derechos sea cancelado o sacrificado sin justificación racional. Este aserto, se ve reforzado por la jurisprudencia y doctrina, especialmente argentina, en tanto sostiene que si las constituciones y tratados internacionales consultan la oralidad, publicidad y la inmediación del juicio y, por otro, el derecho al recurso, lo que corresponde no es entender que un derecho cancela a otro, sino por el contrario, la tarea es encontrar una manera de articular la efectividad de los derechos en juego.

\footnotetext{
109 El mismo planteamiento se encuentra en Marín González, Juan Carlos, "Algunos Aspectos Procesales de la Ley 18.216”, Revista de Estudios de la Justicia $N^{\circ} 10$, 2008, p. 102.

110 Zaffaroni, Eugenio Raúl, Derecho Penal, ob. citada, p. 958.
} 
Barrientos - Recurso efectivo contra la sentencia...

La fórmula propuesta por los fallos analizados más arriba, y que sirve a nuestro modesto objetivo, es la siguiente: Si los arts. 8.5 de la CADH y 14.1 del PIDCP exigen la publicidad del juicio, con lo cual están exigiendo la oralidad e inmediación en el juzgamiento, traducido hoy en nuestro Código Procesal Penal en el juicio oral, y, frente a ellos, los arts. 8.2.h. de la CADH y 14.5 del PIDCP establecen el derecho a recurrir del fallo, condición que cancelaría la primera garantía procesal, no cabe sino interpretar que el segundo exige sólo la revisión de todo aquello que no esté exclusivamente reservado, en cuanto no surge única y directamente de la inmediación, a quienes hayan estado presentes como jueces en el juicio oral.

Asimismo, las dos discriminaciones legislativas que evidencian la falta de racionalidad del sistema de recursos en lo concerniente al cumplimiento alternativo de la pena, no superan, en mi opinión, el test de la justificación racional. Si la ley procesal debe responder a una racionalidad instrumental, por imperativo constitucional expreso, la falta de justificación racional o su inconsistencia lógica, debe ser mirada con sospecha y promover un acucioso examen de los fines de la administración de justicia que están siendo pospuestos.

5.- La noción de revisión integral impide una distinción entre materias que son propias de la sentencia definitiva y otras que no.

En lógica de revisión jurisdiccional integral o amplia, propiciada por los dictámenes y sentencias de organismos internacionales que ejercen control o competencia sobre el cumplimiento de los derechos fundamentales, no se puede negar al imputado el derecho a recurrir del fallo, formulando una distinción que no tiene sustento en el PIDCP ni en la CADH. Lo recurrible, de acuerdo a la CADH, es el fallo, y la parte de la sentencia que se refiere a las medidas alternativas es parte del fallo y, por lo tanto, recurrible. Asimismo, el carácter integral de la revisión de la decisión recurrida impide hacer una distinción entre el ejercicio de atribuciones facultativas o privativas y otras que no tengan ese carácter, para negar la existencia de recurso efectivo respecto de las primeras. El carácter facultativo de una decisión no implica que se trate de una atribución arbitraria o discrecional que no quede sujeta a revisión por un superior jerárquico.

En este punto prestan mucha utilidad las resoluciones del Sistema de Naciones Unidas sobre el derecho a recurrir y, especialmente, sobre el derecho a impetrar la revisión judicial respecto de las medidas no privativas de libertad. Igualmente, el Sistema Interamericano, a través de la Corte Interamericana, marca el rumbo para incluir, en la impugnación todo lo debatido y analizado en el tribunal inferior, lo tocante al cumplimiento alternativo de la pena. Ambos sistemas, fortalecen la fórmula de la revisión integral en cuanto ésta debe abarcar cualquier vicio o error de juicio señalado por el condenado. 


\section{VII. - La necesidad de un cambio.}

La inexistencia de un recurso efectivo, tanto por clausura legal como por clausura judicial, en la medida que colisiona frontalmente con la garantía del derecho al recurso, como integrante del debido proceso, obliga a buscar alguna solución. La más obvia es la enmienda legal. Esta, sin perjuicio del cambio jurisprudencial previo en el Tribunal Supremo, es la opción que se ha seguido en España al permitirse la casación respecto de la infracción de normas constitucionales.

Pero mientras la reforma no se produzca, los tribunales no deben acompañar el lento andar legislativo ${ }^{111}$, pues ello supondría contemplación pasiva de la violación de garantías procesales. Aquí es necesario recordar lo que nos decía el profesor Evans de la Cuadra, si la ley no ha establecido un racional y justo procedimiento corresponde que "la autoridad", entiéndase judicial, quien va aplicar una sanción o que de alguna u otra manera va a afectar derechos, cumpla, antes de resolver, con la exigencia constitucional del "racional y justo procedimiento".

El sistema chileno de recursos penales, en cuanto admite una interpretación progresiva y, con ello, un margen de amplitud mayor al que se concibe en la actualidad, permite una solución al punto crítico que hemos planteado en este trabajo. Los jueces de los tribunales superiores no podrían escudarse en el estricto tenor de la ley, pues al contrario de lo que indica el minimo esfuerzo revisor cuando han querido lograr la revisión de resoluciones de los jueces inferiores que no figuran entre aquellas apelables, han forzado interpretaciones que son demostración de una fructífera imaginación. Un ejemplo de ello, es la impugnabilidad de las resoluciones que declaraban la ilegalidad de la detención sin la existencia de una norma legal que la hiciese procedente. La aplicación seria de las normas internacionales vigentes nos debiera conducir a un escenario más propicio al derecho al recurso, que respetando los principios básicos del juicio oral, no cierre la puerta a quienes, agraviados por una resolución judicial que consideran injusta o errónea, solo pretenden asegurar su libertad personal. Esta es la opción seguida en Argentina e inicial y tímidamente en Costa Rica. ${ }^{112}$

Lo anterior exige tomarse en serio, lo que tantas veces se ha dicho y escuchado: los tratados internacionales, por lo menos, tienen una jerarquía normativa superior a la ley y contienen normas autoejecutables que no requieren de regulación interna.

Si la decisión, legislativa o judicial, pasa por ampliar el recurso de nulidad para permitir la impugnación de la sentencia en aquella parte que niega las medidas alternativas al cumplimiento de la pena, existen tres posibilidades: a) la

111 Términos similares emplea la Corte Suprema argentina en "Casal", en los considerandos 7 y 15.

112 Ver nota $\mathrm{N}^{\circ} 115$. 
Barrientos - Recurso efectivo contra la sentencia...

impugnación por incumplimiento del deber de fundamentación, lo que exigiría la repetición del juicio; b) la impugnación por errónea aplicación del derecho, lo que podría dar lugar, interpretando extensivamente el art. 385 del CPP, a la emisión de sentencia de reemplazo, y; c) la creación de una nueva causal o motivo de nulidad.

La primera posibilidad plantea el problema que de acogerse el recurso, por falta de fundamentación o fundamentación insuficiente, resulta obligatorio el reenvío al tribunal oral para la realización de un nuevo juicio. Juan Carlos Marín González se inclina por considerar que el incumplimiento del art. 24 del la Ley $\mathrm{N}^{\circ}$ 18.216, que exige fundamentar debidamente el rechazo o la concesión de alguna de las medidas alternativas, implica una errónea aplicación del derecho subsumible en el motivo absoluto de nulidad del art. 374 letra e) en relación con el art. 342 letra c) del CPP. ${ }^{113}$ En principio, puede ser una solución adecuada, pero no hay que olvidar que en el mismo caso que Marín González cita en su trabajo (la causa Rol 338-2006 de la Corte de Apelaciones de San Miguel), la sentencia dictada en el segundo juicio impuso una pena que hacia improcedente la concesión de beneficios. Por eso sostenemos que esta solución, sin que se asegure que la prohibición de reformatio in peius rige para el juicio de reenvío, puede ser peligrosa. ${ }^{114}$

Además, la decisión destinada ampliar el recurso de nulidad debe asumir que en los casos en que el interés del recurrente es la concesión de un beneficio, no debería existir el reenvío. Resulta un lujo para el sistema procesal repetir el juicio cuando la resolución, respecto de decisiones denegatorias de beneficios, la pueden tomar los ministros de las Corte de Apelaciones de la misma forma como lo hacen en los casos de decisiones revocatorias. Además quien deduce un recurso por la denegación de un beneficio no pretende la nulidad del juicio, sino sólo de la sentencia. La pretensión es la modificación de sólo una parte de la sentencia, mediante una sentencia de reemplazo. Lo interesante aquí es que el interés del recurrente debe definir los efectos de la decisión que recaerá sobre el recurso.

Me parece, por el momento, que la alternativa más adecuada es subsumir la no concesión de beneficios en la causal del art. 373 letra b) del CPP, es decir, errónea aplicación del derecho. Estoy conciente que esta solución exige una interpretación amplia de la infracción de un precepto legal y que además requiere extender la aplicación del art. 385 del CPP, para que en caso de acogimiento del recurso se dicte sentencia de reemplazo, considerando que se configura la circunstancia de haberse aplicado una pena superior a la que correspondiere legalmente. ${ }^{115}$

\footnotetext{
113 Marín González, Juan Carlos, “Algunos Aspectos Procesales de la Ley 18.216”, Revista de Estudios de la Justicia $N^{\circ} 10,2008$, p. 102.

114 Ver nota $\mathrm{N}^{\circ} 114$. Sobre la prohibición de la reformatio in peius y la realización de nuevo juicio, se puede consultar el trabajo del autor, con el mismo título, en la Revista de Estudios de la Justicia $\mathrm{N}^{\circ}$ 9, 2007, pp. 175-207.

115 La Corte de Apelaciones de Antofagasta en sentencia dictada en causa Rol N 103-2008, de 11 de junio de 2008, acogió nuestro planteamiento, constituyéndose en el primer tribunal superior que
} 
La adopción de esta segunda posibilidad exige que la Corte Suprema y las Cortes de Apelaciones asuman el mandato del art. 5 de la Constitución y del art. 1 y 2 de la CADH y adecuen el sistema de recursos en lo concerniente a la impugnación de la sentencia denegatoria de beneficios, hasta que el legislador proceda a una nueva regulación del recurso de nulidad, haciéndose eco de la noción de revisión integral o amplia, sin que se destruyan con ello los fundamentos del juicio oral y público. Al resolver en este sentido los tribunales superiores no harán sino cumplir rigurosamente con el mandato de la $\mathrm{CADH}$, especialmente el contenido en el art. 2 de dicha convención, adoptando todas las medidas no legislativas que sean necesarias para permitir el pleno uso y goce de los derechos humanos. ${ }^{116}$

La tercera posibilidad pasa por una actividad legislativa, para la que, sin perjuicio de invocar todo el razonamiento precedente, nos permitimos una observación: el efecto normal del acogimiento del recurso cuando sólo se impugne la sentencia por la denegación de beneficios, debe ser la nulidad de la sentencia y no del juicio oral, esto es, no debe existir el reenvío al tribunal oral o de garantía, según corresponda.

Finalmente, una cuestión a elucidar con pretensión de lege ferenda es el carácter unilateral o bilateral del recurso contra la sentencia que se pronuncia sobre beneficios de la Ley $\mathrm{N}^{\circ}$ 18.216. Mi posición en esto es que el recurso debe proceder solamente contra la sentencia que deniega el cumplimiento alternativo de la pena, porque, como es obvio, es el imputado quien sufre la afectación de la libertad personal. En el caso del Ministerio Público y la parte querellante lo que está principalmente en juego es la aplicación efectiva de la ley penal, que en cuanto bien colectivo está supeditado prima facie al derecho individual, sin que la unilateralidad del recurso pueda verse como un quiebre injustificado del principio

acoge la procedencia del recurso de nulidad para cuestionar la no concesión de beneficios de la Ley $\mathrm{N}^{\circ}$ 18.216. Sostiene la Corte que “... debe dejarse sentado la procedencia del recurso de nulidad frente al pronunciamiento sobre los beneficios de la Ley 18.216, respecto de la cual se deja constancia que, si bien en el recurso no fue planteado, en la audiencia se hicieron presente normas constitucionales, tratados internacionales y se invocó las reglas mínimas de las Naciones Unidas sobre las medidas privativas de libertad, conocidas como Reglas Tokio.[...] ... de manera que no es posible dejar en la indefensión al imputado frente a un pronunciamiento condenatorio perjudicial para éste, debiendo el órgano jurisdiccional respetar el debido proceso. Además, el ordenamiento jurídico exige el cumplimiento de los tratados internacionales, a los que el derecho público y la doctrina en general le otorgan un rango constitucional en la obligatoriedad de su aplicación." (Subrayado mío). Sentencia dictada por la Segunda Sala, integrada por los ministros titulares Oscar Clavería Guzmán (redactor), Gabriela Soto Chandía y el Abogado Integrante Roberto Miranda Villalobos. En sentencia de 5 de julio de 2008 la Primera Sala de la Corte de Apelaciones de Antofagasta, en causa Rol de ingreso $\mathrm{N}^{\circ} 123$ 2008, nuevamente acogió un recurso de nulidad en que cuestionaba la no concesión del beneficio de reclusión nocturna.

116 Sobre el particular se puede ver: Medina Quiroga, Cecilia y Nash Rojas, Claudio, Sistema Interamericano de Derechos Humanos. Introducción a sus Mecanismos de Protección, Universidad de Chile, Centro de Derechos Humanos, abril 2007, Santiago de Chile, pp-19-29. 
Barrientos - Recurso efectivo contra la sentencia...

de igualdad. Además, la unilateralidad, es la única forma de evitar la saturación de las Cortes de Apelaciones por recursos de la parte acusadora, sin que pueda objetarse en estos casos este argumento por su carácter funcional o economicista. Asimismo, si de lo que se trata es restaurar una facultad procesal perdida por los imputados con la entrada en vigencia de la Ley $\mathrm{N}^{\circ} 19.806$, debe tenerse en cuenta que el texto derogado del artículo 25 de la Ley 18.216 concedía, sin perjuicio de las reglas generales sobre apelación y consulta, el recurso de apelación al condenado para cuestionar la decisión denegatoria de los beneficios comentados, actuando esta norma como una especie de incentivo para no recurrir contra la declaración condenatoria y la extensión de la pena, con la consecuente limitación jurisdiccional del tribunal de alzada. También la unilateralidad planteada es coherente con las Reglas de Tokio, que en esta materia pueden ser consideradas interpretación auténtica del art. 14.5 del PIDCP, las que establecen el derecho de revisión a solicitud del delincuente. 